\title{
The weekend effect within and downwind of Sacramento: Part 2. Observational evidence for chemical and dynamical contributions
}

J. G. Murphy ${ }^{1,4}$, D. A. Day ${ }^{1,5}$, P. A. Cleary ${ }^{1,6}$, P. J. Wooldridge ${ }^{1}$, D. B. Millet ${ }^{2,7}$, A. H. Goldstein ${ }^{2}$, and R. C. Cohen ${ }^{1,3}$

${ }^{1}$ University of California at Berkeley, Department of Chemistry, USA

${ }^{2}$ University of California at Berkeley, Department of Environmental Science, Policy and Management, USA

${ }^{3}$ University of California at Berkeley, Department of Earth and Planetary Sciences, USA

${ }^{4}$ now at University of East Anglia, School of Environmental Sciences, UK

${ }^{5}$ now at University of California at Davis, Land, Air and Water Resources Department, USA

${ }^{6}$ now at University of Pennsylvania, Department of Chemistry, USA

${ }^{7}$ now at Harvard University, Department of Earth and Planetary Sciences, USA

Received: 30 October 2006 - Accepted: 17 November 2006 - Published: 24 November 2006

Correspondence to: R. C. Cohen (cohen@cchem.berkeley.edu)

Weekend effent in Scaramento: Part 2.

Chemistry and transport

J. G. Murphy et al.

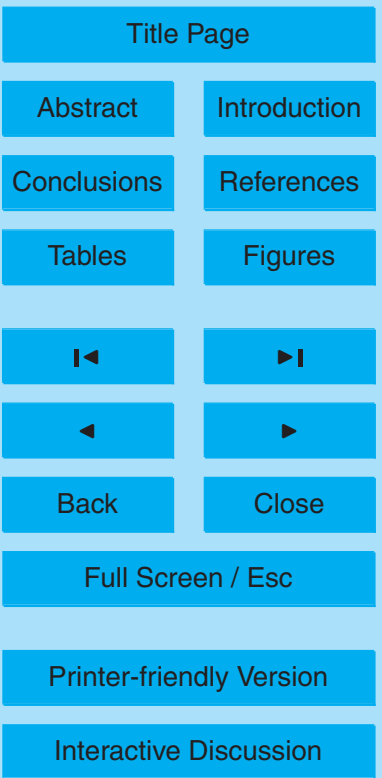




\section{Abstract}

Observations of day-of-week patterns and diurnal profiles of ozone, volatile organic compounds and nitrogen oxides are examined to assess the chemical and dynamical factors governing the daytime ozone accumulation and the distribution of chemically 5 related species in Central California. Isoprene observations show that urban $\mathrm{OH}$ concentrations are higher on the weekend whereas rural $\mathrm{OH}$ concentrations are lower on the weekend, confirming that $\mathrm{NO}_{\mathrm{x}}$ concentrations have a direct effect on the rate of photochemical ozone production and that the transition from $\mathrm{NO}_{\mathrm{x}}$-saturated (VOC-limited) to $\mathrm{NO}_{\mathrm{x}}$-limited chemistry occurs between the city and the downwind rural counties. We quantify the extent to which mixing of ozone and its precursors from aloft contributes to the daytime accumulation of ozone at the surface in Sacramento. Ozone production in the rural Mountain Counties is currently $\mathrm{NO}_{x}$-limited and will decrease in response to $\mathrm{NO}_{\mathrm{x}}$ emission reductions in the Sacramento Valley. However, $\mathrm{NO}_{\mathrm{x}}$ emissions reductions of at least $50 \%$ (from weekday levels) are necessary to bring about a significant decrease in accumulation of ozone at the surface in the Sacramento Valley. The impact of $\mathrm{NO}_{\mathrm{x}}$ emission reductions on the frequency of exceeding the federal 8-hour ozone standard at an individual site will depend on the balance between reduced titration and the sign and magnitude of production changes. We further show that $\mathrm{HNO}_{3}$ production, which depends on the product of $\mathrm{OH}$ and $\mathrm{NO}_{2}$ mixing ratios, is a constant at high $\mathrm{NO}_{\mathrm{x}}$, suggesting that $\mathrm{NO}_{\mathrm{x}}$ must be reduced below a threshold before nitrate aerosol can be expected to decrease.

\section{Introduction}

Day-of-week patterns in emissions provide a clear opportunity to test our understanding of the mechanisms responsible for controlling atmospheric composition. In this 25 paper and its companion, hereafter referred to as Murphy et al. (2006), we examine day-of-week patterns in ozone, speciated nitrogen oxide compounds $\left(\mathrm{NO}_{\mathrm{yi}}\right)$, and re-
Weekend effent in

Scaramento: Part 2.

Chemistry and transport

J. G. Murphy et al.

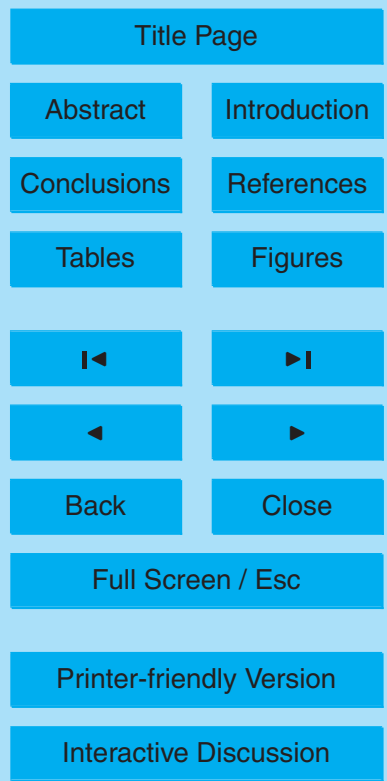


activity of volatile organic compounds (VOC), in the Sacramento Valley and Mountain Counties. We use these observations to provide direct observational measures of photochemical and dynamical processes affecting $\mathrm{O}_{3}, \mathrm{HNO}_{3}$ and the distribution of ozone and aerosol precursors in general. We also specifically examine the seven hypotheses 5 that have been put forward to explain the presence of higher ozone concentrations on the weekend in urban areas (California Air Resources Board, 2003):

1. ozone titration - less suppression of ozone by lower $\mathrm{NO}_{\mathrm{x}}$ emissions on weekend mornings

2. increased weekend emissions - different activity patterns on the weekend actually generate more $_{3}$ precursors

3. aerosol and UV radiation - more of the photons required to initiate ozone production reach the Earth's surface on weekends because of reduced aerosol concentrations

4. $\mathrm{NO}_{\mathrm{x}}$ timing - weekend traffic patterns result in more $\mathrm{NO}_{\mathrm{x}}$ being available during times of high photochemical productivity resulting in more efficient instantaneous ozone production $\left(\mathrm{P}\left(\mathrm{O}_{3}\right)\right)$

5. carryover of precursors at the surface - heavier traffic on Friday and Saturday nights results in a greater availability of $\mathrm{O}_{3}$ precursors at the surface on weekend mornings

6. carryover aloft - large amounts of ozone and precursors persist above the nighttime boundary layer and mix down to the surface the following day in such a way that weekend concentrations are higher in urban areas

7. $\mathrm{NO}_{\mathrm{x}}$ dependence of $\mathrm{P}\left(\mathrm{O}_{3}\right)$ - lower $\mathrm{NO}_{\mathrm{x}}$ on weekends in $\mathrm{NO}_{\mathrm{x}}$-saturated areas leads to more rapid ozone production

\section{Weekend effent in \\ Scaramento: Part 2. \\ Chemistry and transport \\ J. G. Murphy et al.}

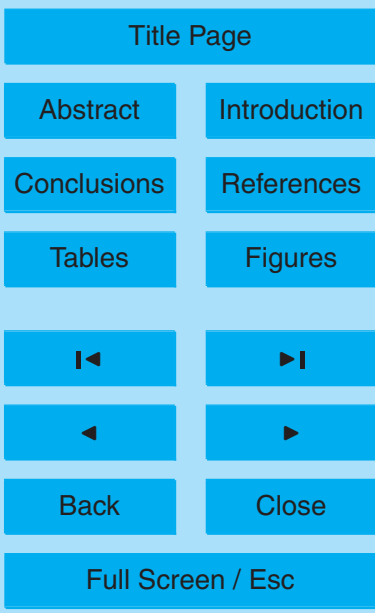

Printer-friendly Version

Interactive Discussion 
In Murphy et al. (2006) we used five years of summertime observations to show that sites within the Sacramento Valley experience higher ozone levels on the weekend, while sites in the downwind Mountain Counties have lower ozone on the weekend, especially on Sundays. The location of the monitoring sites is shown in Fig. 1. In the 5 preceding paper we explored the first three of these hypotheses. At all of the sites in the Sacramento Valley and Mountain Counties where $\mathrm{NO}_{\mathrm{x}}$ measurements are made, Murphy et al. (2006) showed that $\mathrm{NO}_{\mathrm{x}}$ was consistently lower (by about 35\%) on the weekends compared to weekdays, a trend that has been attributed to the significant decrease in diesel traffic on weekends in the region (Marr and Harley, 2002). Speciated 10 VOC measurements at a suburban site, Granite Bay, and a rural site, the University of California Blodgett Forest Research Station (UC-BFRS), allowed us to calculate the weekend effect in VOC reactivity, a change of less than $15 \%$. This small change is due both to the importance of biogenic VOC in the region, and the fact that the dominant change in traffic is from diesel vehicles, which have a smaller impact on VOC abundance than on $\mathrm{NO}_{\mathrm{x}}$ abundance.

The Murphy et al. (2006) analysis of routine observations from the California Air Resources Board showed that higher daytime $\mathrm{NO}_{\mathrm{x}}$ emissions on weekdays results in suppression of ozone concentrations at all of the sites in the Sacramento region. This was demonstrated by comparing the weekend effect in ozone and odd oxygen $\left(\mathrm{O}_{\mathrm{x}} \equiv \mathrm{O}_{3}+\mathrm{NO}_{2}\right)$. Thus hypothesis \#1, ozone titration, was found to contribute to the dayof-week pattern in ozone. Because of this phenomenon, and especially at sites in close proximity to major roads, the pattern in $\mathrm{O}_{\mathrm{x}}$, rather than $\mathrm{O}_{3}$, should be used to examine other factors responsible for the weekend effect. It was further demonstrated that there is no evidence that weekend activity patterns produce a higher concentration of ozoneforming precursors during the 8-hour time period when ozone is highest, confirming that hypotheses \#2 is not important. While $\mathrm{PM}_{2.5}$ concentrations in the Sacramento Valley were lower on Sunday, there was no clear indication that the photolysis rates of ozone, formaldehyde and $\mathrm{NO}_{2}$ or the emission rates of biogenic VOC were significantly affected showing hypothesis \#3 is unimportant.

\section{Weekend effent in \\ Scaramento: Part 2. Chemistry and transport}

J. G. Murphy et al.

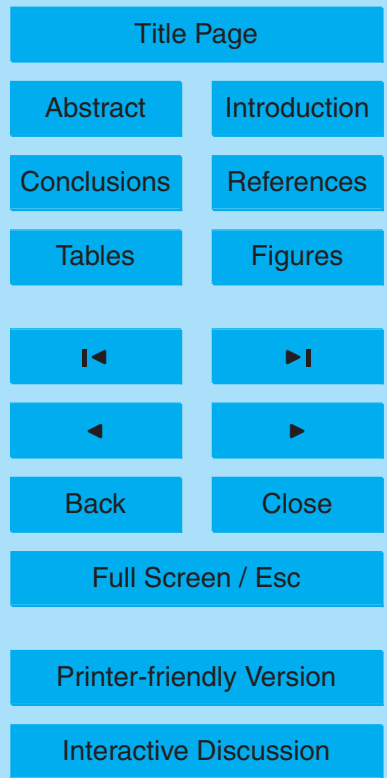


Here we extend the analysis to examine the four remaining hypotheses put forward to explain the weekend effect in ozone, which are related to the dynamical and nonlinear chemical processes that control the day-of-week patterns in the concentrations of ozone and its precursors. In Sect. 2 of this paper we examine diurnal profiles in $5 \mathrm{O}_{3}, \mathrm{NO}_{\mathrm{x}}$, and VOC reactivity at several sites showing that different activity patterns on weekends do not generate higher precursor concentrations during time periods of efficient ozone production (hypothesis \#4). The diurnal patterns also show that higher traffic on Friday and Saturday nights does not result in a greater availability of ozone precursors on weekend mornings, and that hypothesis \#5 is not responsible for day-of10 week patterns in $\mathrm{O}_{\mathrm{x}}$. In Sect. 3, we establish some metrics for evaluating hypotheses \#6 and \#7: studying the rate of accumulation of $O_{x}$ in the surface layer at each site by selecting the $4 \mathrm{~h}$ over which concentrations tend to increase most rapidly. In Sect. 4 we develop an analytical model describing the non-linear dependence of $\mathrm{HO}_{\mathrm{x}}$ and the instantaneous production rates of ozone and nitric acid on $\mathrm{NO}_{\mathrm{x}}$ for assessment of hy15 pothesis \#7. The model builds on earlier analytical work by Kleinman et al. (2001) and on direct observational tests of models of ozone production rates by Thornton et al. (2002). We use the model to provide a quantitative estimate of how ozone production rates, $\mathrm{OH}$ concentrations and other trace gases respond to $\mathrm{NO}_{\mathrm{x}}$ both in the high $\mathrm{NO}_{\mathrm{x}}$ (also referred to as the $\mathrm{NO}_{\mathrm{x}}$-saturated or VOC-limited regime) and in the low $\mathrm{NO}_{\mathrm{x}}$ (or $\mathrm{NO}_{\mathrm{x}}$-limited) regime. In Sect. 5 we examine hypothesis \#6 and use the observations to quantify the contribution of carryover from the previous day (days) of $O_{x}$ and its precursors aloft to the daytime accumulation of ozone at the surface. Section 6 provides further tests of the relative importance of hypotheses \#6 and \#7 using speciated measurements of VOC and higher nitrogen oxides $\left(\mathrm{NO}_{\mathrm{z}}=\mathrm{RO}_{2} \mathrm{NO}_{2}+\mathrm{RONO} \mathrm{N}_{2}+\mathrm{HNO}_{3}\right)$ as additional indicators of the oxidative capacity of the surface layer and the mixing down of processed air. Finally, we conclude with a discussion of the emission reductions required to reduce the number of exceedances of the 8-hour ozone standard in the Sacramento Valley and Mountain Counties.
Weekend effent in

Scaramento: Part 2.

Chemistry and transport

J. G. Murphy et al.

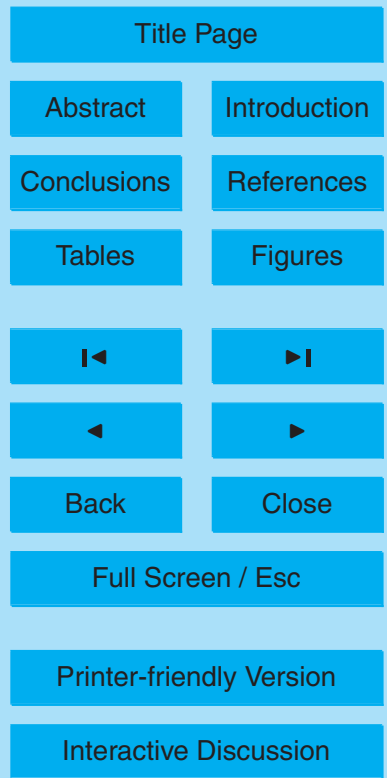




\section{Timing and carryover of emissions at the surface}

The day-of-week trends in maximum 8-hour average ozone concentrations were examined in Murphy et al. (2006), along with the average abundance of $\mathrm{NO}_{\mathrm{x}}$ and VOC precursors during the $8 \mathrm{~h}$ when ozone was generally highest. For sites in the Sacra5 mento Valley this time period was 10:00-18:00 (all times are Pacific Standard Time), and for the rural downwind sites, University of California Blodgett Forest Research Station (UC-BFRS) and Big Hill, the time period was 12:00-20:00 PST. To examine the role of the different timing of $\mathrm{NO}_{x}$ emissions by day of week, we can compare the diurnal profiles of $\mathrm{NO}_{x}$ and $\mathrm{O}_{x}\left(\right.$ or $\mathrm{O}_{3}$ ) at three different sites. Routine monitoring data can be used indirectly to infer changes in the magnitude and timing of emissions. In order to address the importance of changes in timing of emissions, we compare diurnal trends in $\mathrm{NO}_{\mathrm{x}}$ abundance over the day as solar radiation and VOC reactivity are changing. In Figs. 2-4 and through much of the following analysis, data from Tuesday, Wednesday, and Thursday, days which are expected to have very similar emission profiles, have been combined generating an average weekday (TWT) to simplify interpretation of the graphics. While no effort was made to recategorize holidays in the five year data sets, the $\mathrm{NO}_{\mathrm{x}}$ and VOC data sets obtained at the UC-BFRS and Granite Bay are shorter making proper classification of a single day more important. Labor Day Monday was counted as a Sunday and the following Tuesday was then counted as a Monday for these sites.

Figures $2 a$ and $2 b$ show diurnal profiles of $\mathrm{NO}_{x}$ and $\mathrm{O}_{\mathrm{x}}$ at $\mathrm{T}$ Street, a site close to downtown Sacramento. While weekday-weekend differences in the concentrations of $\mathrm{NO}_{\mathrm{x}}$ are largest during morning rush hour, weekend $\mathrm{NO}_{\mathrm{x}}$ is lower throughout the day. Perhaps the most remarkable feature of Fig. 2 is that despite a 50\% weekday-weekend difference in $\mathrm{NO}_{x}$ abundance at midday, the odd oxygen concentrations observed at the site have very similar profiles for every day of the week. As we discuss in Murphy et al. (2006), the proximity of the T Street site to Highway $50(\sim 400 \mathrm{~m})$ likely means that the bulk of $\mathrm{NO}_{\mathrm{x}}$ observed by the monitor has not had time to influence ozone production

\section{Weekend effent in \\ Scaramento: Part 2. Chemistry and transport \\ J. G. Murphy et al.}

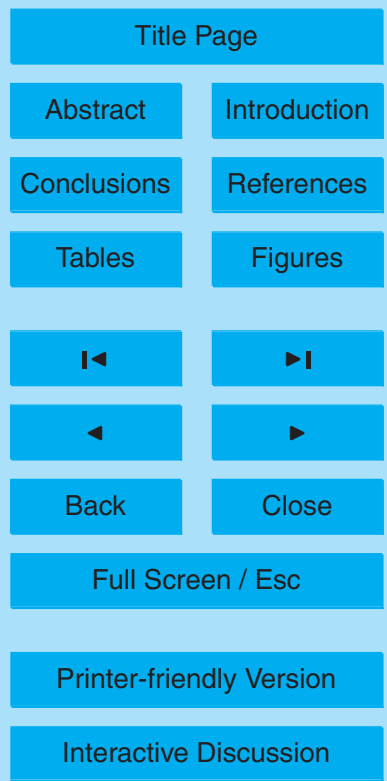


in the airmass.

Figures $3 a$ and $3 b$ show the $\mathrm{NO}_{x}$ and $\mathrm{O}_{x}$ diurnal profiles at the Folsom site, located in the suburbs on the eastern edge of the Sacramento region. $\mathrm{NO}_{\mathrm{x}}$ concentrations (and by inference emissions) vary less during the day on the weekends than on weekdays.

5 The important fact is that weekend concentrations never exceed weekday concentrations. The availability of higher $\mathrm{NO}_{\mathrm{x}}$ on weekdays does not appear to lead to higher $\mathrm{O}_{\mathrm{x}}$ concentrations even at midday, when the most rapid ozone production could be expected. The timing of odd oxygen changes share some subtle but common features at both the Folsom and T Street sites. The maximum tends to occur earlier on Sunday, 10 with a broader distribution and lower peak concentrations. In contrast, $\mathrm{O}_{\mathrm{x}}$ peaks latest in the day on Friday, which is also the day with the highest peak concentration at both sites.

Figure 4 shows $\mathrm{NO}_{x}$ and $\mathrm{O}_{3}$ profiles at the UC-BFRS site. $\mathrm{O}_{3}$ was used rather than $\mathrm{O}_{x}$ for the summers of 1998-2002 because the $\mathrm{O}_{3}$ record is more complete than the $15 \mathrm{O}_{\mathrm{x}}$ record and observations show that the contribution of $\mathrm{NO}_{2}$ to odd oxygen at this rural site is negligible. The diurnal trends at this rural site differ in important ways from the data in Figs. 2 and 3. The early morning decrease in ozone is due to the opening of plant stomata, which leads to rapid ozone loss by deposition (Kurpius and Goldstein, 2003). Shortly thereafter, the nighttime boundary layer begins to break up, mixing down higher levels of ozone and nitrogen oxides (Day, 2003), present in layers of the troposphere that were disconnected from surface during the night. Urban emissions from Sacramento begin to influence the UC-BFRS site around noon after several hours of upslope flow. Between 12:00 and 20:00, during the upslope influence of the plume, $\mathrm{NO}_{\mathrm{x}}$ is lower at the site on weekends, whereas ozone is lowest on Sunday 25 and Monday. The timing of $\mathrm{NO}_{x}$ and $\mathrm{O}_{3}$ are governed more strongly by transport at this site than by nearby emissions, and it is difficult to identify a direct role for the timing of emissions. Additionally, in a $\mathrm{NO}_{\mathrm{x}}$-limited environment such as is present at the UCBFRS, the number of $\mathrm{O}_{3}$ molecules produced per $\mathrm{NO}_{x}$ emitted is less strongly coupled to the $\mathrm{NO}_{x}$ concentration, and $\mathrm{P}\left(\mathrm{O}_{3}\right)$ scales with $\mathrm{NO}_{x}$ concentration linearly, reducing

Weekend effent in

Scaramento: Part 2. Chemistry and transport

J. G. Murphy et al.

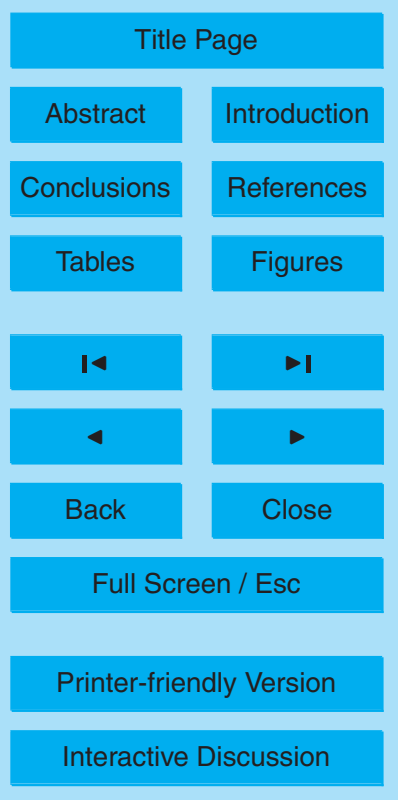

EGU 
the importance of timing.

Figures 2, 3, and 4 show that weekend emission patterns never produce higher concentrations of $\mathrm{NO}_{\mathrm{x}}$ (hypothesis \#4) and that carryover of $\mathrm{O}_{3}$ precursors at the surface after Friday and Saturday nights (hypothesis \#5) is unimportant. While Friday night 5 has substantially higher $\mathrm{NO}_{\mathrm{x}}$ concentrations at Folsom, the highest late night $\mathrm{NO}_{x}$ at $T$ Street is observed on Sunday. At both sites, by the time morning rush hour starts the following day, the memory of emission patterns from the previous night are almost completely lost. Given the importance of biogenic VOC to total VOC reactivity in the region (Murphy et al., 2006), a substantial day-of-week pattern in the carryover of VOC at 10 the surface is unlikely. To confirm this interpretation, the diurnal profile in VOC and CO reactivity at Granite Bay and the UC-BFRS from July-September of 2001 are shown in Fig. 5 (CO data from Del Paso was used as an estimate for the abundance at Granite Bay, where it was not measured). A full list of compounds included in the analysis can be found in Rubin et al. (2006). The relatively short datasets, as well as the smaller 15 weekend effect in VOC versus $\mathrm{NO}_{x}$ results in much less precise assessment of day-ofweek differences in VOC reactivity compared to $\mathrm{NO}_{\mathrm{x}}$. Data prior to morning rush hour (Granite Bay) or the breakup of the nocturnal boundary layer (the UC-BFRS) do not indicate that Saturday and Sunday mornings have substantially higher residual VOC reactivity at the surface. Some of the differences in reactivity that we observe are a consequence (as we show in Sect. 6) of the decrease in $\mathrm{NO}_{\mathrm{x}}$ on weekends and the associated changes in $\mathrm{OH}$ concentration-higher $\mathrm{OH}$ on weekends in the urban areas results in lower VOC reactivity and lower $\mathrm{OH}$ on the weekend in rural areas results in an increase in reactivity.

The $\mathrm{O}_{\mathrm{x}}$ and $\mathrm{O}_{3}$ profiles shown in Figs. 2-4 have all been plotted on the same scale to 25 facilitate comparison between the sites. The diurnal trend at the UC-BFRS is common throughout the Mountain Counties with peak ozone occurring in the later afternoon or early evening depending on the distance of the site from Sacramento. Perhaps more striking than differences between the sites during the daytime is the significantly higher nighttime mixing ratio of $\mathrm{O}_{\mathrm{x}}$ observed at the UC-BFRS in comparison to $\mathrm{T}$ Street and

\section{Weekend effent in \\ Scaramento: Part 2. Chemistry and transport \\ J. G. Murphy et al.}

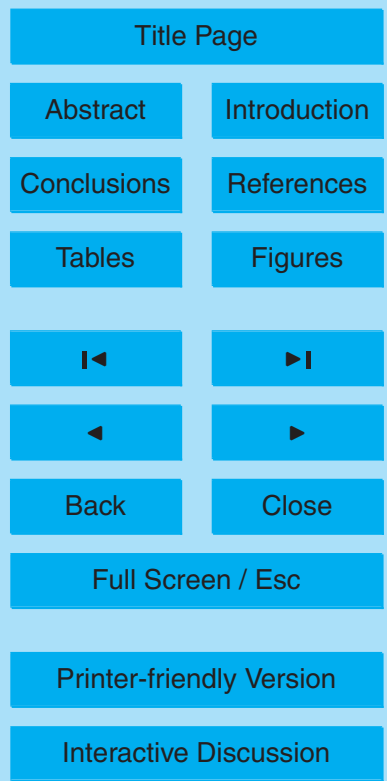


Folsom. This is a general feature found throughout the sites analyzed: nighttime $\mathrm{O}_{x}$ concentrations are much lower in the urban environment than nighttime $\mathrm{O}_{3}$ concentrations at the rural sites. The most likely explanation for greater nocturnal losses of $\mathrm{O}_{x}$ in urban areas is the conversion of $\mathrm{NO}_{2}$ to $\mathrm{N}_{2} \mathrm{O}_{5}$ followed by $\mathrm{N}_{2} \mathrm{O}_{5}$ hydrolysis on aerosol 5 surfaces to form $\mathrm{HNO}_{3}$. In the presence of sufficient water and aerosol surface area, the rate of the loss of odd oxygen is given by $\mathrm{L}\left(\mathrm{O}_{\mathrm{x}}\right)=2 \mathrm{k}_{\mathrm{NO}_{2}+\mathrm{O}_{3}}\left[\mathrm{NO}_{2}\right]\left[\mathrm{O}_{3}\right]$. This process is therefore optimized under conditions where the odd oxygen is divided evenly between $\mathrm{O}_{3}$ and $\mathrm{NO}_{2}$. During the night, sites in Sacramento have $\mathrm{L}\left(\mathrm{O}_{\mathrm{x}}\right)$ between 1 and $3 \mathrm{ppb} / \mathrm{hr}$, whereas at the UC-BFRS, a rural site where $\mathrm{O}_{\mathrm{x}}$ is dominated by $\mathrm{O}_{3}$, this rate

10 is only $0.1 \mathrm{ppb} / \mathrm{hr}$. Regardless of the cause of these rapid nighttime losses in urban areas, maximum 8-hour averages of $\mathrm{O}_{3}$ or $\mathrm{O}_{x}$ rarely include data from before 10:00 at the urban sites, but often do at the rural sites.

\section{Factors governing odd oxygen increases}

In general, between 08:00 and 09:00, as the nocturnal boundary layer begins to break 15 up and morning rush hour traffic decreases near urban sites, there are very small day-of-week differences in odd oxygen. The slightly lower odd oxygen on weekend mornings observed in Figs. 2 and 3 may be the result of a reduction in $\mathrm{NO}_{\mathrm{x}}$ emissions of which a small fraction $(<15 \%)$ may be direct $\mathrm{NO}_{2}$ emissions (Carslaw and Beevers, 2005), which are equivalent to $O_{x}$ production. By 09:00, the dominant daytime wind direction has been established: flow from the SSW at the surface in the Valley and WSW at higher altitudes bringing urban emissions from south to north over Sacramento and upslope toward the sites in the Mountain Counties. Between 09:00 and 13:00, the concentration of odd oxygen at the urban sites in the Sacramento Valley increases nearly linearly on most days during the summer (1998-2002). The timing of the daily increase in ozone at the rural sites in the Mountain Counties is more variable and depends on the proximity of each site to the urban source of ozone precursors. The lack of $\mathrm{NO}_{2}$ measurements by the California Air Resources Board at its Mountain Counties

Weekend effent in

Scaramento: Part 2. Chemistry and transport

J. G. Murphy et al.

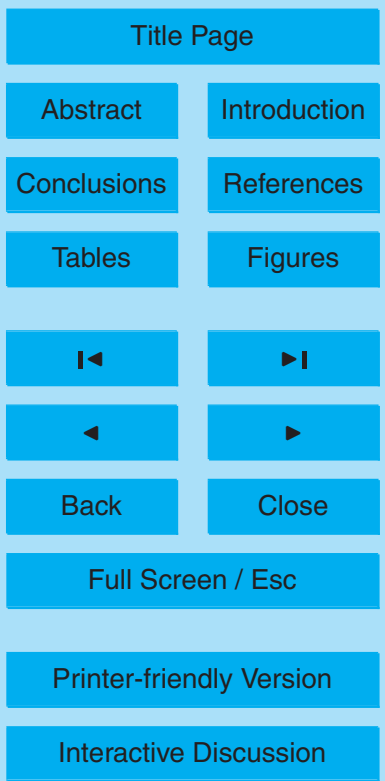


sites requires the use of $\mathrm{O}_{3}$ data in our analysis when total $\mathrm{O}_{x}$ would be preferable. In general, we expect the contribution of $\mathrm{NO}_{2}$ to $\mathrm{O}_{x}$ to be small at rural sites but possibly non- negligible, particularly at the Colfax and Placerville monitoring sites, which are both located less than $500 \mathrm{~m}$ from highways.

To examine the day-of-week pattern in the rise of ozone concentrations, the change in odd oxygen $\left(\Delta \mathrm{O}_{\mathrm{x}}\right)$ has been calculated by taking the difference between measurements at 13:00 and 09:00 at urban sites for different days of the week. This data is compiled in Table 1, with Tuesday, Wednesday and Thursday data combined. In Table 2, the average concentration of $\mathrm{NO}_{\mathrm{x}}$ at each site between 09:00 and 13:00 is tab10 ulated. For the sites in the Mountain Counties, we select the $4 \mathrm{~h}$ period during which $\mathrm{O}_{3}$ measurements have the steepest increase, consistent with the timing of the arrival of the urban plume from Sacramento. Table 3 shows the rise in ozone $\left(\Delta \mathrm{O}_{3}\right)$ at the Mountain Counties sites for the appropriate $4 \mathrm{~h}$ period. In each table, the final column was calculated by combining the individual sites to come up with a basin-wide value for 15 each day, and then dividing that value by the basin-wide weekly mean. This is mathematically equivalent to finding the normalized trend for each site and then averaging throughout the basin. This gives a qualitative sense of which days of the week have higher and lower values for each air basin.

These basin-wide trends are shown in Fig. 6, with error bars encompassing the range of values observed at the individual sites. The top panel shows the rise in $\Delta \mathrm{O}_{\mathrm{x}}$ and the $\mathrm{NO}_{\mathrm{x}}$ concentration during that time period normalized to the weekly mean for the sites in the Sacramento Valley. Consistent with daytime average $\mathrm{NO}_{x}$ concentrations described in Murphy et al. (2006), $\mathrm{NO}_{\mathrm{x}}$ concentrations between 09:00 and 13:00 are substantially lower on the weekend at all sites in the Sacramento Valley. The lowest $\Delta \mathrm{O}_{\mathrm{x}}$ occurs on Monday for every site in the Sacramento Valley, and the highest $\Delta \mathrm{O}_{\mathrm{x}}$ on Saturday (8\% lower and $8 \%$ higher than the weekly basin-wide average, respectively). Sunday has intermediate rates of $\mathrm{O}_{\mathrm{x}}$ increases, similar to TWT and Friday, despite having only half as much $\mathrm{NO}_{\mathrm{x}}$. There is very little variability in the normalized day-ofweek trends in $\Delta \mathrm{O}_{\mathrm{x}}$ amongst the different sites in the Sacramento Valley, suggesting

\section{Weekend effent in \\ Scaramento: Part 2. Chemistry and transport}

J. G. Murphy et al.

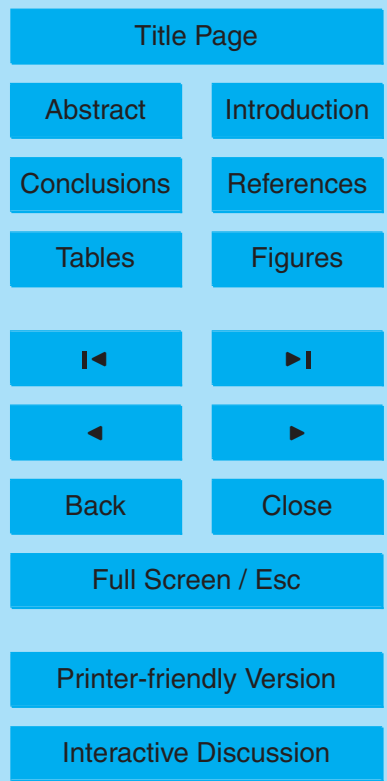

11980 
that the balance of processes controlling the production and accumulation of ozone in airmasses upwind of these sites is similar. From this analysis it appears that there are important differences between Saturday and Sunday, and between Monday and other weekdays. The day-of-week pattern in surface ozone does not simply follow the day5 of-week trend in surface $\mathrm{NO}_{\mathrm{x}}$ concentrations, but also appears to be influenced by the emission pattern of the previous day.

For the Mountain Counties sites shown in the bottom panel of Fig. 6, we calculate the rise in ozone $\left(\Delta \mathrm{O}_{3}\right)$ for the $4 \mathrm{~h}$ period which generally exhibits the most rapid change observed at each site individually. In the absence of CARB $\mathrm{NO}_{x}$ monitors in 10 the Mountain Counties, we rely on the UC-BFRS data to represent the trend in $\mathrm{NO}_{\mathrm{x}}$ throughout the Mountain Counties. Given the close agreement between the normalized day-of-week trends in $\mathrm{NO}_{x}$ at the UC-BFRS and the upwind urban sites, it seems that this pattern likely holds throughout the Mountain Counties region. In the Mountain Counties, weekends have lower $\mathrm{NO}_{x}$ concentrations and generally smaller increases 15 in ozone during the time period when the urban plume is influencing the sites. However, the trends are not totally consistent among all the sites in the Mountain Counties. Sunday has the lowest $\Delta \mathrm{O}_{3}, 14 \%$ lower throughout the basin than the weekly average. Monday had lower $\Delta \mathrm{O}_{3}$ than Saturday at sites closer to Sacramento (Cool, Colfax), whereas the opposite was true at more remote sites like the UC-BFRS and White Cloud. If the majority of the ozone in airmasses reaching the rural sites was produced under $\mathrm{NO}_{\mathrm{x}}$-limited conditions, then we would expect the day-of-week cycle in $\Delta \mathrm{O}_{3}$ to be as strong as the day-of-week cycle in average $\mathrm{NO}_{\mathrm{x}}$. There are several possible reasons why we see a weaker or inconsistent trend in $\Delta \mathrm{O}_{3}$ at some of the Mountain Counties sites: 1) local $\mathrm{NO}_{\mathrm{x}}$ emissions may be influencing observations, for example Friday and 25 Sunday afternoon traffic along Highways 50 and 80 likely depress the slope of $\Delta \mathrm{O}_{3}$ at Placerville and Colfax, 2) sites like Cool are close enough to urban sources that some of the ozone production in airmasses arriving at the site is probably not $\mathrm{NO}_{\mathrm{x}}$-limited, and 3 ) the rural sites may be affected by carryover of ozone above the surface. Despite the wider variability in $\Delta \mathrm{O}_{3}$ in the Mountain Counties as compared to $\Delta \mathrm{O}_{\mathrm{x}}$ in the Sacra-

\section{Weekend effent in \\ Scaramento: Part 2. Chemistry and transport}

J. G. Murphy et al.

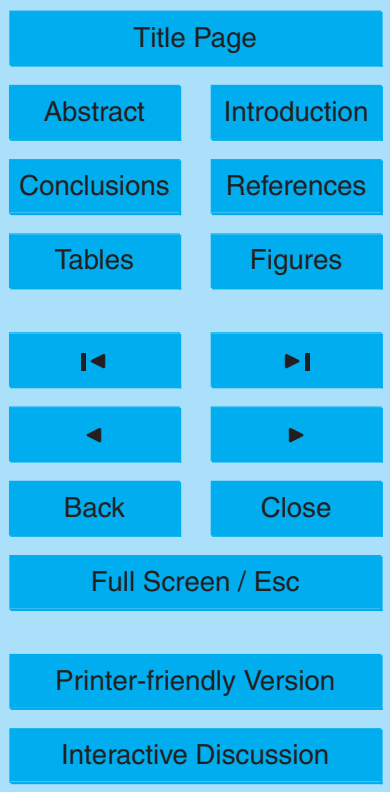

\section{1}


mento Valley, the rural sites do demonstrate generally lower ozone increases on the weekends as compared to weekdays, and the two most remote sites, the UC-BFRS and White Cloud follow the pattern expected from $\mathrm{NO}_{\mathrm{x}}$-limited production.

The observed change in $\mathrm{O}_{x}$ concentrations reflects the combination of upwind pro5 cesses affecting ozone including production, deposition, mixing and chemical losses integrated over the appropriate timescale $(\sim 4 \mathrm{~h})$. During the morning hours when concentrations are increasing, production and mixing outweigh the effect of chemical losses and deposition. Neither loss nor deposition is expected to have a day-of-week pattern.

\section{Modeling the dependence of $\mathrm{HO}_{x}$ and the production of $\mathrm{O}_{3}$ and $\mathrm{NO}_{z}$ on $\mathrm{NO}_{\mathrm{x}}$}

In this section, we develop a model that describes the instantaneous rate of ozone production $\mathrm{P}\left(\mathrm{O}_{3}\right)$ as a function of $\mathrm{NO}_{x}$ concentration, for a specified VOC reactivity and production rate of odd hydrogen radicals $\mathrm{P}\left(\mathrm{HO}_{\mathrm{x}}\right)$. We use surface observations of $\mathrm{NO}_{\mathrm{x}}$ and VOC to predict the magnitude and day-of-week pattern of $\mathrm{P}\left(\mathrm{O}_{3}\right)$ at the surface

15 in the Sacramento Valley and Mountain Counties. In order to derive equations that describe the $\mathrm{NO}_{\mathrm{x}}$-dependence of the hydroxyl radical $[\mathrm{OH}]$, peroxy radicals $\left[\mathrm{HO}_{2}+\mathrm{RO}_{2}\right]$ and $\mathrm{P}\left(\mathrm{O}_{3}\right)$, we use the reactions describing $\mathrm{HO}_{x}$ chain propagation and termination and the conservation statement for odd hydrogen radicals $\left(\mathrm{HO}_{\mathrm{x}}=\mathrm{OH}+\mathrm{HO}_{2}+\mathrm{RO}_{2}\right)$ :

$$
\mathrm{P}\left(\mathrm{HO}_{\mathrm{x}}\right)=\mathrm{L}\left(\mathrm{HO}_{\mathrm{x}}\right) \text {. }
$$

Reactions that propagate the $\mathrm{HO}_{\mathrm{x}}$ cycle and lead to ozone production by the oxidation of $\mathrm{NO}$ to $\mathrm{NO}_{2}$ include

$\mathrm{VOC}+\mathrm{OH} \stackrel{\mathrm{O}_{2}}{\longrightarrow} \mathrm{RO}_{2}+\mathrm{H}_{2} \mathrm{O}$

$\mathrm{RO}_{2}+\mathrm{NO} \rightarrow \mathrm{RO}+\mathrm{NO}_{2}$

$\mathrm{RO}+\mathrm{O}_{2} \rightarrow \mathrm{R}^{\prime} \mathrm{CHO}+\mathrm{HO}_{2}$

Weekend effent in

Scaramento: Part 2.

Chemistry and transport

J. G. Murphy et al.

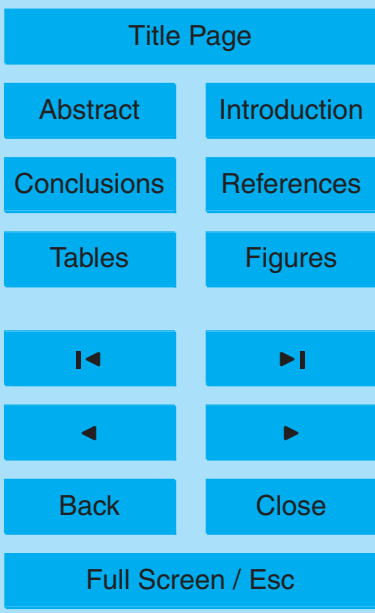

Printer-friendly Version

Interactive Discussion 
$\mathrm{HO}_{2}+\mathrm{NO} \rightarrow \mathrm{OH}+\mathrm{NO}_{2}$

Reactions that terminate the $\mathrm{HO}_{\mathrm{x}}$ cycle and lead to the production of nitric acid, alkyl nitrates $\left(\mathrm{RONO}_{2}\right.$ or $\left.\Sigma \mathrm{ANs}\right)$ or peroxides include

$\mathrm{OH}+\mathrm{NO}_{2}+\mathrm{M} \rightarrow \mathrm{HNO}_{3}+\mathrm{M}$

$5 \mathrm{RO}_{2}+\mathrm{NO}+\mathrm{M} \rightarrow \mathrm{RONO}_{2}+\mathrm{M}$

$\mathrm{RO}_{2}+\mathrm{R}^{\prime} \mathrm{O}_{2} \rightarrow \mathrm{ROOR}^{\prime}+\mathrm{O}_{2}$

$\mathrm{RO}_{2}+\mathrm{HO}_{2} \rightarrow \mathrm{ROOH}+\mathrm{O}_{2}$

$\mathrm{HO}_{2}+\mathrm{HO}_{2} \rightarrow \mathrm{H}_{2} \mathrm{O}_{2}+\mathrm{O}_{2}$

The formation of alkyl nitrates (R2c) is a secondary branch of the reaction of organic 10 peroxy radicals with NO. The probability of forming an alkyl nitrate depends on the identity of the $\mathrm{R}$ group, and is denoted here as $\alpha=\mathrm{k}_{2 c} /\left(\mathrm{k}_{2 a}+\mathrm{k}_{2 c}\right)$. The formation of peroxynitrates $\left(\mathrm{RO}_{2} \mathrm{NO}_{2}\right.$ or $\left.\Sigma \mathrm{PNs}\right)$, most significantly PAN, may also reversibly partition radicals into a reservoir form in which they cannot participate in ozone production

$\mathrm{RC}(\mathrm{O}) \mathrm{O}_{2}+\mathrm{NO}_{2}+\mathrm{M} \Leftrightarrow \mathrm{RC}(\mathrm{O}) \mathrm{O}_{2} \mathrm{NO}_{2}+\mathrm{M}$

15 We assume that peroxynitrates are in steady state with the radicals, which simplifies the equations considerably. Additionally, if the $\mathrm{NO}_{x}$ dependence of peroxyacyl radicals follows that of total organic and hydroperoxy radicals $\left[\mathrm{HO}_{2}+\mathrm{RO}_{2}\right]$, the gross production of peroxyacyl nitrates has the same $\mathrm{NO}_{x}$ dependence as $\mathrm{O}_{3}$. Net production of $\Sigma$ PNs may affect the magnitude of ozone production, but it should have a negligible effect on 20 its $\mathrm{NO}_{\mathrm{x}}$-dependence.

Substituting the $\mathrm{HO}_{\mathrm{x}}$ loss reactions into Eq. (1) yields

$\mathrm{P}\left(\mathrm{HO}_{\mathrm{x}}\right)=\mathrm{k}_{4}[\mathrm{OH}]\left[\mathrm{NO}_{2}\right]+\mathrm{k}_{2 \mathrm{c}}\left[\mathrm{RO}_{2}\right][\mathrm{NO}]+2 \mathrm{k}_{5 \mathrm{a}}\left[\mathrm{RO}_{2}\right]\left[\mathrm{R}^{\prime} \mathrm{O}_{2}\right]$

$+2 \mathrm{k}_{5 \mathrm{~b}}\left[\mathrm{RO}_{2}\right]\left[\mathrm{HO}_{2}\right]+2 \mathrm{k}_{5 \mathrm{c}}\left[\mathrm{HO}_{2}\right]\left[\mathrm{HO}_{2}\right]$

Weekend effent in

Scaramento: Part 2. Chemistry and transport

J. G. Murphy et al.

Title Page

Abstract Introduction

Conclusions

14

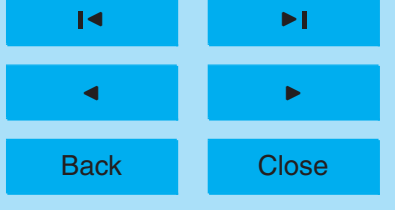

Full Screen / Esc

Printer-friendly Version

Interactive Discussion 
Under conditions of rapid ozone production, chain propagation is more important than chain termination. With a high chain length, every cycle that produces an $\mathrm{RO}_{2}$ radical through $\mathrm{R} 1$, will go on to produce an $\mathrm{HO}_{2}$ radical through subsequent $\mathrm{R} 2 \mathrm{a}$ and $\mathrm{R} 3$, and we can therefore simplify relationships among $\mathrm{HO}_{x}$ constituents to find

$5 \quad\left[\mathrm{HO}_{2}\right]=\left[\mathrm{RO}_{2}\right]=\frac{\mathrm{k}_{1}[\mathrm{VOC}][\mathrm{OH}]}{\mathrm{k}_{2}[\mathrm{NO}]}$

Expressing the effective rate of $\mathrm{NO}$ oxidation by peroxy radicals as $\mathrm{k}_{2 \mathrm{eff}}$ and the effective rate of all peroxy radical self-reactions as $k_{5 \text { eff }}$ and using Eq. (3) to simplify further we find:

$\mathrm{P}\left(\mathrm{HO}_{\mathrm{x}}\right)=\mathrm{k}_{4}[\mathrm{OH}]\left[\mathrm{NO}_{2}\right]+\alpha \mathrm{k}_{2 \mathrm{eff}} \frac{\mathrm{k}_{1}[\mathrm{VOC}][\mathrm{OH}]}{\mathrm{k}_{2 \mathrm{eff}}[\mathrm{NO}]}[\mathrm{NO}]+6 \mathrm{k}_{5 \mathrm{eff}}\left(\frac{\mathrm{k}_{1}[\mathrm{VOC}][\mathrm{OH}]}{\mathrm{k}_{2 \mathrm{eff}}[\mathrm{NO}]}\right)^{2}$

10 Using the quadratic formula, we can derive an expression for the concentration of the hydroxyl radical,

$$
[\mathrm{OH}]=\frac{-\left(\mathrm{k}_{4}\left[\mathrm{NO}_{2}\right]+\alpha \mathrm{k}_{1}[\mathrm{VOC}]\right)+\sqrt{\left(\mathrm{k}_{4}\left[\mathrm{NO}_{2}\right]+\mathrm{ak}_{1}[\mathrm{VOC}]\right)^{2}+24 \mathrm{P}\left(\mathrm{HO}_{\mathrm{x}}\right) \mathrm{k}_{5 \mathrm{eff}}\left(\frac{\mathrm{k}_{1}[\mathrm{VOC}]}{\mathrm{k}_{\text {2eff }}[\mathrm{NO}]}\right)^{2}}}{12 \mathrm{k}_{5 \text { eff }}\left(\frac{\mathrm{k}_{1}[\mathrm{VOC}]}{\mathrm{k}_{\text {2eff }}[\mathrm{NO}]}\right)^{2}}
$$

The concentration of peroxy radicals can be calculated according to Eq. (3), and the production rate of $\mathrm{O}_{3}$ (in the case of $\alpha<<1$ ) simplifies to

$\mathrm{P}\left(\mathrm{O}_{3}\right)=\mathrm{k}_{2 \text { eff }}\left[\mathrm{HO}_{2}+\mathrm{RO}_{2}\right][\mathrm{NO}]=2 \mathrm{k}_{1}[\mathrm{VOC}][\mathrm{OH}]$

Parameters needed to solve these equations are given in Table 4. The first four input parameters are based on surface observations made in the Sacramento region and downwind. The last two rows represent estimates of the effective rate constants for the generic reaction of peroxy radicals with $\mathrm{NO}(\mathrm{R} 2)$ and with another peroxy radical (R5). The concentrations of $\mathrm{OH}$ and peroxy radicals predicted by the model as a function

Weekend effent in

Scaramento: Part 2.

Chemistry and transport

J. G. Murphy et al.

\section{Title Page}

Abstract Introduction

Conclusions

14

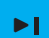

4

Back

Close

Full Screen / Esc

Printer-friendly Version

Interactive Discussion 
of $\mathrm{NO}_{x}$ are shown in Fig. 7. The maximum concentration of $\mathrm{OH}$ occurs at an intermediate $\mathrm{NO}_{x}$ close to $4 \mathrm{ppb}$, representing the optimal balance between $\mathrm{OH}$ production through $\mathrm{R} 2$ and $\mathrm{OH}$ destruction through $\mathrm{R} 4$. Because of the simplified representation of ozone production in the model, Fig. 8 demonstrates that $\mathrm{P}\left(\mathrm{O}_{3}\right)$ has the same $5 \mathrm{NO}_{\mathrm{x}}$-dependence as $[\mathrm{OH}]$. Figure 8 also shows the $\mathrm{NO}_{\mathrm{x}}$ dependence of the production rate of nitric acid $\mathrm{P}\left(\mathrm{HNO}_{3}\right)$ which plateaus at high $\mathrm{NO}_{x}$ concentrations where $[\mathrm{OH}]$ becomes inversely proportional to $\left[\mathrm{NO}_{\mathrm{x}}\right]$. The production of organic nitrates from $\mathrm{RO}_{2}$ and $\mathrm{NO}_{\mathrm{x}}$ has the same $\mathrm{NO}_{\mathrm{x}}$ dependence as $\mathrm{P}\left(\mathrm{O}_{3}\right)$ and a magnitude that depends on the composition of $\mathrm{RO}_{2}$.

10 To estimate the magnitude of ozone production and its $\mathrm{NO}_{\mathrm{x}}$ dependence, the instantaneous production rate is integrated according to the $\mathrm{NO}_{\mathrm{x}}$ conditions experienced upwind for the preceding $\mathrm{O}_{\mathrm{x}}$ lifetime $(\sim 4 \mathrm{~h})$. The time dependence of the $\mathrm{NO}_{\mathrm{x}}$ concentration upwind of a rural site like the UC-BFRS is straightforward to calculate if we assume that Sacramento is the dominant source of $\mathrm{NO}_{\mathrm{x}}$ to the site. In that case, $\mathrm{NO}_{\mathrm{x}}$ 5 concentrations fall off logarithmically between the eastern edge of Sacramento and the downwind location due to dilution and photochemistry. Concentrations of $\mathrm{NO}_{\mathrm{x}}$ at the UC-BFRS are one-sixth of those at Granite Bay, an eastern suburb, suggesting that the product of the loss rate and transit time $\left(\mathrm{k}_{\text {loss }}{ }^{*} \mathrm{t}\right)$ is approximately 2 (i.e. $\left.6^{-1} \sim(2 \mathrm{e})^{-1}\right)$. If the airmass traveled from the Sacramento suburbs to the UC-BFRS in $4 \mathrm{~h}$, consistent with observed local wind speeds, and with a $\mathrm{NO}_{\mathrm{x}}$ loss rate of $0.5 \mathrm{~h}^{-1}$, the $\mathrm{NO}_{\mathrm{x}}$ concentration would fall off as it appears in the top panel of Fig. 9. Throughout the entire time evolution of the plume, $\mathrm{NO}_{\mathrm{x}}$ concentrations are approximately one third lower on the weekend. Using the relationship between the instantaneous ozone production rate and $\mathrm{NO}_{\mathrm{x}}$ concentration derived from the model and shown in Fig. 8, we can deter25 mine $\mathrm{P}\left(\mathrm{O}_{3}\right)$ along the airmass trajectory upwind of Blodgett, shown in the lower panel of Fig. 9. If $\mathrm{P}\left(\mathrm{O}_{3}\right)$ is integrated over the lifetime of ozone $(\sim 4 \mathrm{~h})$, the model predicts gross ozone production will be $20 \%$ higher on weekdays (56 ppb) compared to the weekend $(47 \mathrm{ppb})$. This is consistent with data compiled for the UC-BFRS in Table 3 where ozone increases on Monday-Friday are approximately $20 \%$ higher than $\Delta \mathrm{O}_{\mathrm{x}}$ on

\section{Weekend effent in \\ Scaramento: Part 2. Chemistry and transport}

J. G. Murphy et al.

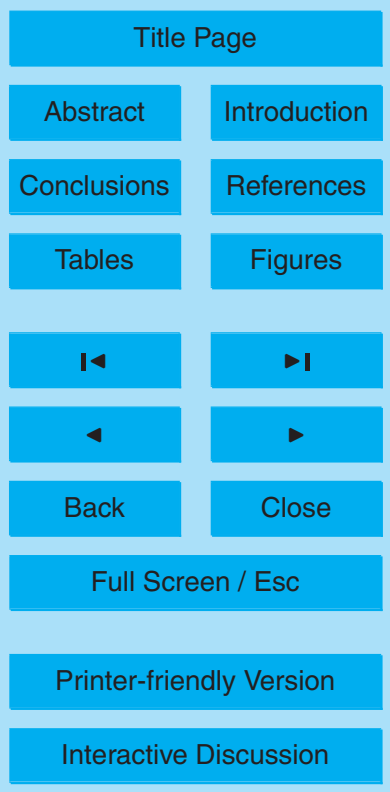


Saturday-Sunday. Note that the model suggests that the initial point for this calculation, in the eastern Sacramento suburbs, is in the $\mathrm{NO}_{\mathrm{x}}$-saturated regime on weekdays. $\mathrm{NO}_{\mathrm{x}}$ removal as the plume moves east results first in an increase in $\mathrm{P}\left(\mathrm{O}_{3}\right)$ with a peak production rate about $1 \mathrm{~h}$ downwind on weekdays. On weekends the model suggests that 5 the initial point is at approximately the peak of $\mathrm{P}\left(\mathrm{O}_{3}\right)$ and for the first $45 \mathrm{~min}(25 \%$ decrease in $\mathrm{NO}_{\mathrm{x}}$ ) the ozone production rate changes little. After this time $\left(\mathrm{NO}_{\mathrm{x}}\right.$ decrease) ozone production decreases almost linearly with the $\mathrm{NO}_{x}$ decrease. This calculation uses parameters appropriate for local noon, when ozone production is at its peak. As discussed in Thornton et al. (2002) at other times of day the transition from $\mathrm{NO}_{\mathrm{x}}$-limited to $\mathrm{NO}_{\mathrm{x}}$-saturated ozone production occurs at lower $\mathrm{NO}_{\mathrm{x}}$.

The time dependence of the $\mathrm{NO}_{\mathrm{x}}$ concentration in an airmass as it moves over the Sacramento metropolitan area cannot be predicted in such a straightforward manner. Roseville, Folsom, and Granite Bay are sites on the northeastern (downwind) edge of the urban area and therefore monitor airmasses that have spent a significant portion of the $4 \mathrm{~h}$ ozone production lifetime directly over the city. Although the heterogeneity of $\mathrm{NO}_{\mathrm{x}}$ sources in Sacramento is impossible to model in exact detail using the sparse observational data, we have strong evidence that the weekend/weekday ratio in $\mathrm{NO}_{\mathrm{x}}$ is consistently two-thirds and we can approximate the heterogeneity of sources by adding occasional pulses of $\mathrm{NO}_{\mathrm{x}}$. The $\mathrm{NO}_{\mathrm{x}}$ concentration profile shown in the upper panel of Fig. 10 is an approximation to the observed distribution. The concentration spans the range observed at the monitoring sites in Sacramento, from suburban sites with relatively minor nearby sources, to measurements made within hundreds of meters of major highways. The range of concentrations is such that the model predicts decreasing $\mathrm{P}\left(\mathrm{O}_{3}\right)$ with increasing $\mathrm{NO}_{\mathrm{x}}$. The lower panel of Fig. 10 shows the calculated instantaneous ozone production over the Sacramento urban area. In this case the integrated gross production on the weekday ( $57 \mathrm{ppb}$ ) is estimated to be $20 \%$ lower on the weekday than the weekend (69 ppb). These production rates are 2-3 times larger than the accumulation rates of odd oxygen observed at the surface in the urban core and 3-4 times larger than accumulation rates in the Mountain Counties. Chemical removal

Weekend effent in

Scaramento: Part 2. Chemistry and transport

J. G. Murphy et al.

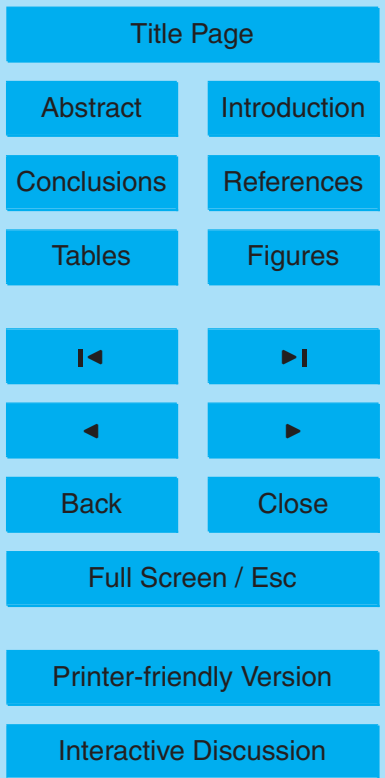

11986 
and deposition of ozone are responsible for about $25 \%$ of the imbalance. It is also possible that failure of the steady state assumption for peroxynitrates contributes. For example, if there is net production of $\Sigma P N s$ in an amount corresponding to $10 \%$ of the gross production rate, then $\mathrm{P}\left(\mathrm{O}_{3}\right)$ can be overestimated by as much as $25 \%$. However,

5 this error in the magnitude of $\mathrm{P}\left(\mathrm{O}_{3}\right)$ is only weakly coupled to the $\mathrm{NO}_{\mathrm{x}}$ dependence of $\mathrm{P}\left(\mathrm{O}_{3}\right)$ and affects the position of the crossover between $\mathrm{NO}_{\mathrm{x}}$-limited and $\mathrm{NO}_{\mathrm{x}}$-saturated chemistry by less than $10 \%$.

Throughout the week, $\mathrm{NO}_{\mathrm{x}}$ concentrations in the Sacramento Valley are predicted by the model to result in NOx-saturated ozone production. Therefore, if the chemistry 10 represented in this model were the only mechanism responsible for $\mathrm{O}_{\mathrm{x}}$ variation with day-of-week, there would be higher rates of $\Delta \mathrm{O}_{\mathrm{x}}$ on the weekend and this accumulation would lead to higher observations of odd oxygen on the weekend in Sacramento. However, the observed day-of-week trends in $\Delta \mathrm{O}_{\mathrm{x}}$ in the Sacramento Valley (Table 1, Fig. 6) do not follow an inverse correlation with surface observations of $\mathrm{NO}_{\mathrm{x}}$ concen15 trations. The other chemical factors which influence $\mathrm{P}\left(\mathrm{O}_{3}\right)$, such as VOC reactivity and $\mathrm{P}\left(\mathrm{HO}_{\mathrm{x}}\right)$, have relatively small day-of-week variations, too small (and not always of the right sign) to be responsible for the pattern in $\Delta \mathrm{O}_{\mathrm{x}}$ seen in Fig. 6 and Table 1.

\section{The importance of carryover aloft in the Sacramento Valley}

The most likely explanation for the pattern in $\Delta \mathrm{O}_{x}$ observed at surface sites in the 20 Sacramento Valley is a combination of local production and the mixing down of ozone in a residual layer aloft. Either the ozone itself is carried over from previous days or precursors emitted on the previous day (or days) establish the photochemical regime for ozone production in the layer aloft. The dominant flow patterns between the Sacramento Valley and Mountain Counties during the summer months are well-known at the 25 surface, and summarized for several sites in Murphy et al. (2006), however much less in known about flow patterns aloft. Using measurements obtained by a wind profiler in the summer of 2000, Zhong et al. (2004) determined that the wind direction over

Weekend effent in

Scaramento: Part 2. Chemistry and transport

J. G. Murphy et al.

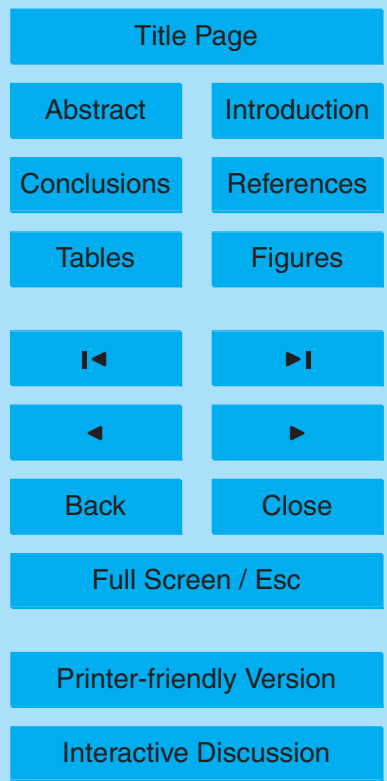


Sacramento airport from 150 to $1050 \mathrm{~m}$ above the surface was persistently westerly or southwesterly over the 24-hour diurnal cycle. In the early morning hours, drainage flow from the Sierra Nevada mountains in the Central Valley causes the winds to shift to southeasterlies at the surface.

5 During the day, surface heating leads to a boundary layer, often deeper than $1000 \mathrm{~m}$, through which emissions from the surface can become relatively well-mixed. Upslope flow along the western slope of the Sierra Nevada draws air from the Sacramento Valley toward the higher elevation Mountain Counties, and there is likely a return flow recycling air back into the Valley at higher altitudes above the surface. At night, radiative cooling 10 of the surface induces air to flow back toward the Valley floor. The boundary layer becomes much shallower at night, and above it there exists a residual layer, distinct from the free troposphere in that it has been more heavily influenced by emissions from the surface which have been mixed in over the preceding day or days. The following morning, as surface heating causes the nocturnal boundary layer to break up, the residual layer can mix back down and influence the surface.

Detailed meteorological and chemical measurements and models in other urban areas with complex terrain such as Mexico City (Bossert, 1997; Jazcilevich et al., 2003) and Phoenix (Lee, et al., 2003), have shown evidence of polluted airmasses returning to the city after being advected upslope. In the Phoenix Sunrise Experiment, early morning vertical profiles of ozone concentrations showed significantly lower values in the lowest $200 \mathrm{~m}$ above the surface until the breakup of the nocturnal boundary layer mixed air down from above. Flow patterns calculated by Lee et al. (2003) using the mesoscale model MM5 confirmed that airmasses that carried emissions upslope away from Phoenix during the day often recirculated back toward the city at night. Combining measurements from three surface sites in Switzerland with a turbulence model Neu et al. (1994) showed that more than half of the daytime ozone accumulation at the surface following nighttime depletion could be attributed to downward mixing from the residual layer. Similarly, observations at UC-BFRS (Fig. 4) show depletion of ozone in a stable layer due to stomatal uptake followed by replenishment when the boundary layer

\section{Weekend effent in \\ Scaramento: Part 2. Chemistry and transport}

J. G. Murphy et al.

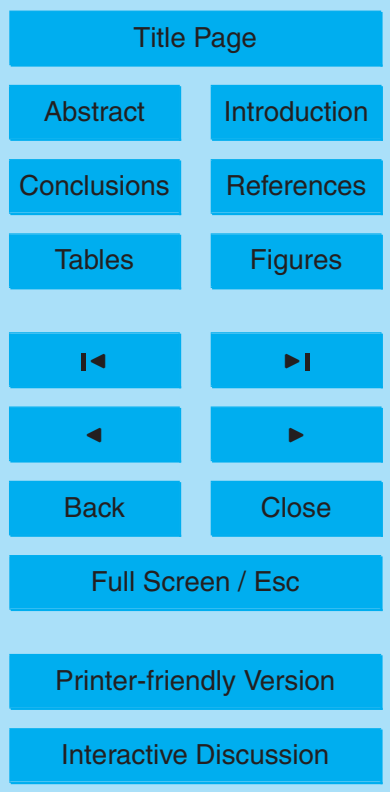


breaks up later in the morning.

The origin of air in the residual layer above Sacramento could be Sacramento itself in the case of stagnant conditions, or if daytime return flow or nighttime drainage directs the processed urban plume back over the city. Alternately, the air could originate in 5 the San Francisco Bay Area, located roughly $100 \mathrm{~km}$ to the southwest of Sacramento. When the nocturnal boundary layer over Sacramento breaks up after sunrise, air that hasn't undergone significant losses in odd oxygen can mix back down to the surface, causing concentrations of ozone and odd oxygen to recover. This phenomenon likely accounts for part of the increase in odd oxygen observed at urban sites (Figs. 2-3) 10 between 06:00 and 09:00, when it is too early for rapid photochemical production to occur. There are few measurements of the vertical distribution of ozone over Sacramento, however observations made from a Cessna 182 in the summers of 1995 and 1996 observed high concentrations of residual ozone above the surface layer in the early morning hours (Carroll and Dixon, 2002). From the analysis of seven days of 15 observations, the authors concluded that these high concentrations of ozone in the residual layer ( $>70 \mathrm{ppb}$ ) were necessary to produce high afternoon concentrations in the surface layer (>120 ppb).

Observations of $\mathrm{CO}$ and long-lived hydrocarbons at the Del Paso, Folsom, Granite Bay, and the UC-BFRS monitoring sites have been used to estimate the lifetime 20 for mixing between the boundary layer and the residual layer along the transect from the Sacramento Valley to the Mountain Counties (Dillon et al., 2002). This analysis suggests the timescale for this mixing is roughly $4 \mathrm{~h}\left(\mathrm{k}_{d} \sim 0.25 \mathrm{~h}^{-1}\right)$. If this rate is also applicable to an airmass moving from south to north over the Sacramento urban area $\left(\sim 25 \mathrm{~km}\right.$ at $\left.8 \mathrm{~km} \mathrm{~h}^{-1}\right)$, by the time it is sampled at a surface site at the northern edge of 25 the city, it will be approximately equally comprised of air from the boundary layer and residual layer. In other words, the rate of increase in odd oxygen is best characterized by equal contributions from the boundary and residual layers.

Air in the residual layer is more photochemically aged than the boundary layer and can therefore be expected to have lower concentrations of $\mathrm{NO}_{\mathrm{x}}$. The residual layer

\section{Weekend effent in \\ Scaramento: Part 2. Chemistry and transport}

J. G. Murphy et al.

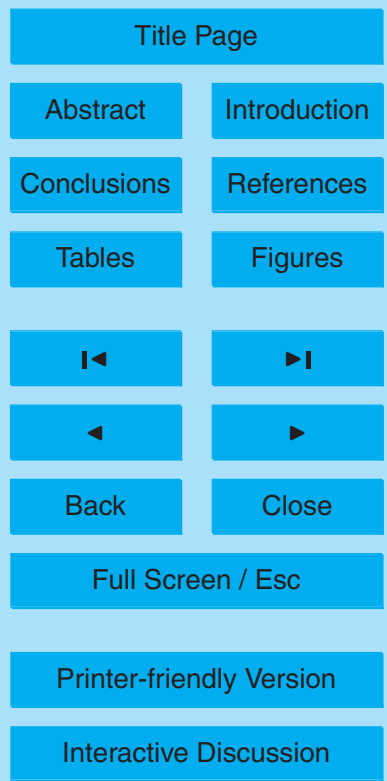

\section{9}


was connected with the surface the previous day and therefore bears the pattern of emissions of the previous day. Further, we can expect that by the time this airmass was incorporated into the residual layer, ozone production was $\mathrm{NO}_{\mathrm{x}}$-limited and that it continues to be so the following day. With this in mind, we generate Table 5, which 5 indicates the qualitative day-of-week patterns in the rates of ozone production in the boundary layer $\left(\mathrm{NO}_{\mathrm{x}}\right.$-saturated) and the residual layer $\left(\mathrm{NO}_{\mathrm{x}}\right.$-limited) from the city of Sacramento. The penultimate column shows the predicted rate of odd oxygen increase in an airmass equally influenced by the boundary and residual layers, which matches very well with the observed relative rates of $\Delta \mathrm{O}_{\mathrm{x}}$ at the sites in the Sacramento Valley. 10 A more quantitative perspective can be obtained by comparing pairs of days where conditions are similar aloft but different at the surface. Sunday and Monday (or Friday and Saturday) both have residual layers characteristic of the weekend (weekday) but different concentrations at the surface. Using data in Tables 1 and 2 shows that for both pairs $\Delta \mathrm{O}_{\mathrm{x}}$ is $\sim 7 \%$ higher on days with $\sim 35 \%$ less $\mathrm{NO}_{\mathrm{x}}$ at the surface. This shows that $15 \mathrm{P}\left(\mathrm{O}_{3}\right)$ decreases with increasing $\mathrm{NO}_{\mathrm{x}}$ but not strongly, thus ozone production must be close to the crossover between $\mathrm{NO}_{\mathrm{x}}$-limited and $\mathrm{NO}_{\mathrm{x}}$-saturated.

Regardless of their origin, the recycling of airmasses from aloft results in a carryover effect which modulates the day-of-week pattern in ozone concentrations. The carryover effect likely plays out differently for sites in the Mountain Counties than in Sacramento. Most sites in the Mountain Counties are sufficiently distant from the urban emission sources at the surface, that both the boundary and residual layers contain precursor concentrations that bear the signature of the current day of emissions. Consistent with this idea, the more remote sites, Placerville, the UC-BFRS and White Cloud, have lower $\Delta \mathrm{O}_{3}$ on Saturday than on Monday. Sites that are closer to the city, such as Cool and Colfax are similar to the urban sites with Monday lower than Saturday.

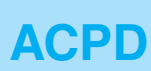

6, 11971-12019, 2006

Weekend effent in

Scaramento: Part 2.

Chemistry and transport

J. G. Murphy et al.

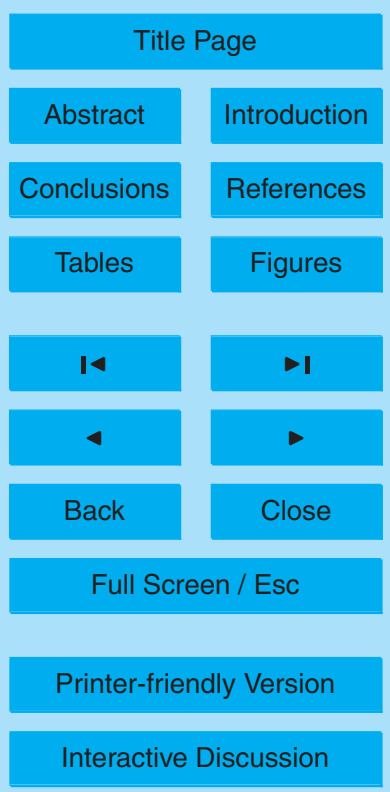




\section{Additional indicators of production and mixing}

The day-of-week patterns observed in this region show that the advection of emissions from Sacramento controls the timing and magnitude of increases in ozone at Mountain Counties sites. They also demonstrate that the recycling of processed airmasses with 5 relatively high ozone and low $\mathrm{NO}_{\mathrm{x}}$ into the Sacramento Valley sets the stage for odd oxygen increases on a given day. $\mathrm{NO}_{x}$ and VOC emissions are the source of photochemical ozone production, and measurements of speciated nitrogen oxides and VOC can offer additional insights into the photochemical regime under which the ozone in an airmass was produced. In this analysis, we make use of observations made by UC

10 Berkeley researchers at the UC-BFRS and Granite Bay in the summer of 2001. The limited duration of the datasets compels us to examine the daytime averages rather than the morning rise as was possible for the longer term $\mathrm{O}_{3}$ records. Nevertheless, average daytime concentrations of speciated VOC and oxidized reactive nitrogen allow us to constrain the $\mathrm{NO}_{\mathrm{x}}$-dependence of ozone formation and the role of transport and 15 recycling.

VOC were measured at Granite Bay and the UC-BFRS during the summer of 2001 using fully automated, in situ, two-channel gas chromatograph/mass selective detector/flame ionization detector (GC/MSD/FID) systems (Lamanna and Goldstein, 1999; Millet et al., 2005). The main sink for most VOC emitted in this region is oxidation by the hydroxyl radical, with a timescale ranging from minutes to weeks, depending on the VOC species. The lifetimes of reactive VOC are inversely proportional to the local $\mathrm{OH}$ concentration. Biogenic VOC do not have any known day-of-week patterns in their emissions, but meteorological factors such as temperature and light can cause their emissions to vary widely. For this reason, we also include a longer term measurement series of the biogenic VOC isoprene in the Sacramento Valley, from the Photochemical Assessment Monitoring Station (PAMS) at Del Paso. The lifetime of isoprene with respect to $\mathrm{OH}$ is short (less than $1 \mathrm{~h}$ ), so isoprene concentrations are a powerful probe of local $\mathrm{OH}$ abundance. The top panel of Fig. 11 shows the day-of-week pattern in

\section{Weekend effent in \\ Scaramento: Part 2. Chemistry and transport \\ J. G. Murphy et al.}

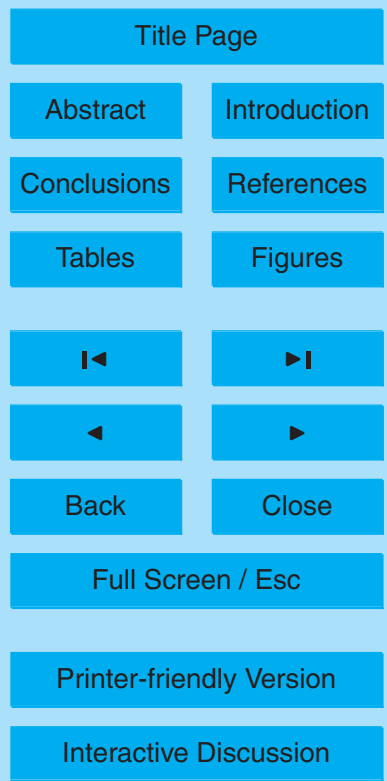


isoprene concentrations between 12:00 and 15:00 during the summers of 1994-2003. Isoprene concentrations are slightly higher on weekdays, suggesting that less $\mathrm{OH}$ is present in the urban airmass on the weekdays. Observations of $\mathrm{NO}_{\mathrm{x}}$ at Del Paso described in Murphy et al. (2006) show that daytime average $\mathrm{NO}_{\mathrm{x}}$ concentrations in5 creased from 6 to $12 \mathrm{ppb}$ from Sunday to Friday. According to model predictions shown in Fig. 7, $\mathrm{OH}$ concentrations should decrease with increasing $\mathrm{NO}_{\mathrm{x}}$ in this range. This pattern confirms that the instantaneous production rate of ozone $\mathrm{P}\left(\mathrm{O}_{3}\right)$ based on precursor concentrations at the surface is $\mathrm{NO}_{\mathrm{x}}$-saturated. There is no clear day-of-week trend in the observations of isoprene at Granite Bay, shown in the middle panel of 10 Fig. 11. This is consistent with relatively small changes in local $\mathrm{OH}$ near the site between weekdays and weekends, in agreement with the crossover between $\mathrm{NO}_{\mathrm{x}}$-limited and $\mathrm{NO}_{x}$-saturated $\mathrm{P}\left(\mathrm{O}_{3}\right)$ occurring near this location as indicated in Fig. 7. The lower panel of Fig. 11 shows the day-of-week pattern in measurements of the sum of several long-lived $\left(\tau \sim 0.5-2\right.$ days at $[\mathrm{OH}]=5 \mathrm{E} 6$ molecules $\left./ \mathrm{cm}^{3}\right)$ anthropogenic VOC (benzene, 15 butane, isobutane, pentane, and isopentane). Emissions of these compounds are expected to be slightly lower on the weekend, yet Monday has the lowest concentrations of any day of the week. This pattern is consistent with the importance of mixing down of pollutants from aloft. For long-lived VOC, the concentration pattern reflects a weighted integral of the sources and sinks over the past several days: air in the Sacramento Valley is influenced by anthropogenic emissions made over the previous day(s) due to recycling of its own emissions and/or transport from other urban areas.

Figure 12 is a companion to Fig. 11 and shows speciated VOC measurements from the UC-BFRS. The top panel compiles summer afternoon isoprene observations made from 1997-2001. The main source of the isoprene observed at the UC-BFRS is an oak belt located east of Sacramento in the lower elevation Sierra Nevada. In the afternoon, the isoprene is emitted into the Sacramento urban plume as it advects upslope and the emissions are processed at a rate that depends on the local chemical environment. Higher isoprene observations on weekends at this remote site indicate that $\mathrm{OH}$ concentrations upwind of the UC-BFRS must be substantially lower on the weekend.

\section{Weekend effent in \\ Scaramento: Part 2. Chemistry and transport}

J. G. Murphy et al.

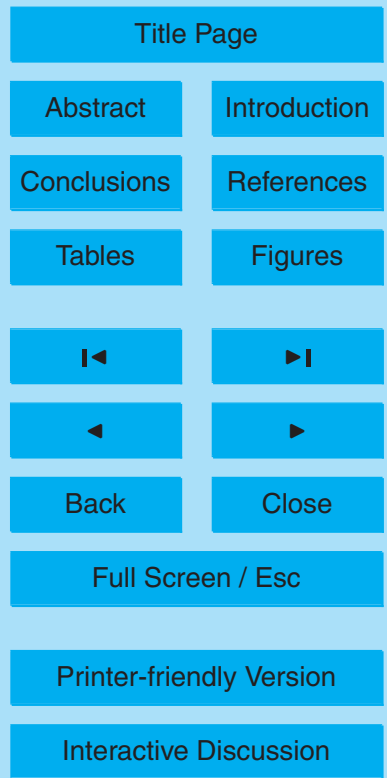


Decreased $\mathrm{OH}$ under conditions of decreased $\mathrm{NO}_{\mathrm{x}}$ agrees with model predictions for the behavior in a $\mathrm{NO}_{\mathrm{x}}$-limited environment. The lower panel of Fig. 12 shows that the concentrations of long-lived compounds at the UC-BFRS build up during the week and decrease on the weekend. Mixing between the boundary and residual layers continues 5 as the urban plume is advected toward the Mountain Counties. Given the timescale of the mixing and the arrival time of the plume at the UC-BFRS, both the boundary and residual layers should bear the signature of the current day's emissions. The difference in day-of-week patterns in long-lived VOC at the suburban and rural site may result from the differing importance of dilution and oxidation as sinks in the region.

10 Thermal dissociation laser-induced fluorescence (TD-LIF) was used to measure $\mathrm{NO}_{2}$, total peroxy nitrates ( $\Sigma \mathrm{PNs}$ ), total alkyl nitrates ( $\Sigma \mathrm{ANs}$ ) and $\mathrm{HNO}_{3}$ at Granite Bay from July-September 2001 (Cleary et al., 2005) and at the UC-BFRS from 20002005 (Day, 2003). Measurements made using a commercial $\mathrm{NO}$ and $\mathrm{NO}_{\mathrm{y}}$ analyzer confirm that the compounds measured by TD-LIF represent more than $90 \%$ of $\mathrm{NO}_{\mathrm{y}}$ at 15 the UC-BFRS. Daytime concentrations of NO are estimated at Granite Bay based on steady state with $\mathrm{NO}_{2}$, as a function of radiation and temperature measurements, and the concentration of oxidants. In the following figures and analysis, total reactive nitrogen oxides are defined as $\mathrm{NO}_{y} \equiv \mathrm{NO}+\mathrm{NO}_{2}+\Sigma \mathrm{PNs}+\Sigma \mathrm{ANs}+\mathrm{HNO}_{3}$. The top two panels in Fig. 13 show the day-of-week patterns in the individual compounds measured by the 20 TD-LIF at Granite Bay between 10:00 and 18:00. While $\mathrm{NO}_{2}$ concentrations change by a factor of two between weekday and weekend, nitric acid concentrations vary by less than $20 \%$. This is consistent with the $\mathrm{NO}_{\mathrm{x}}$-saturated urban environment upwind, in which $\mathrm{OH}$ concentrations are inversely proportional to $\mathrm{NO}_{2}$, and $\mathrm{P}\left(\mathrm{HNO}_{3}\right)$ is nearly constant. A constant rate of $\mathrm{HNO}_{3}$ production at high $\mathrm{NO}_{\mathrm{x}}$ also explains the observa25 tions of $\mathrm{HNO}_{3}$ and aerosol nitrate in the South Coast Air Basin, which were found by Blanchard and Tanenbaum (2003) and Motallebi et al. (2003) to have no day-of-week dependence despite large changes in $\mathrm{NO}_{\mathrm{x}}$ emissions. The production of aerosol nitrate from $\mathrm{HNO}_{3}$ will also depend on the abundance of ammonium and sulphate, but as their sources are not dominated by transportation, they are expected to have smaller

\section{Weekend effent in \\ Scaramento: Part 2. Chemistry and transport \\ J. G. Murphy et al.}

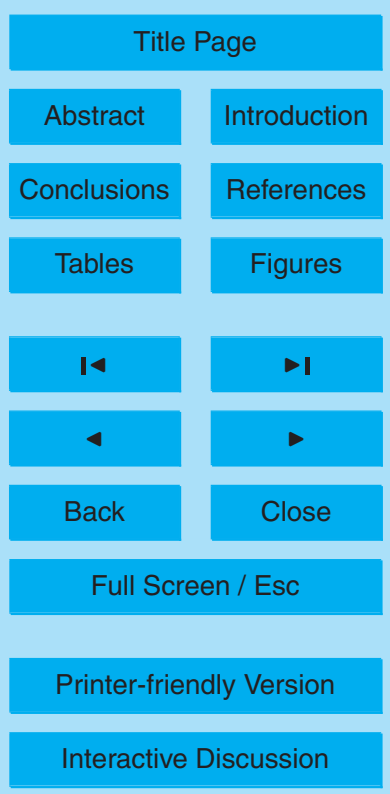

11993 
day-of-week dependences.

The middle panel of Fig. 13 shows the pattern in organic nitrates observed at the Granite Bay site. Alkyl nitrates are co-produced with ozone and therefore can be expected to share a similar pattern with odd oxygen in the urban environment. Peroxyni5 trates stable enough to exist at the surface are formed through the association reactions of peroxyacyl radicals and $\mathrm{NO}_{2}$. The pattern of observations with lower values of both types of organic nitrates on Sunday and Monday suggests that the carryover effect is important for these compounds. For $\Sigma$ PNs, this is possibly due to the carryover of long-lived precursors such as acetone. The bottom panel of Fig. 13 shows day-of10 week patterns related to the oxidation rate and efficiency of $\mathrm{NO}_{\mathrm{x}}$ to produce ozone. The ratio of $\mathrm{NO}_{z}$ to $\mathrm{NO}_{\mathrm{x}}$ is highest on weekends, suggesting that emissions of $\mathrm{NO}_{\mathrm{x}}$ are more quickly oxidized to $\mathrm{NO}_{z}$ in a lower $\mathrm{NO}_{\mathrm{x}}$ environment. This is consistent with the $\mathrm{NO}_{x}$-dependence of the $\mathrm{OH}$ and $\mathrm{RO}_{2}$ radicals predicted in Fig. 7 .

Figure 14 shows speciated nitrogen oxide data from the UC-BFRS during the sum15 mer of 2001. The oxidation of $\mathrm{NO}_{\mathrm{x}}$ to $\mathrm{NO}_{\mathrm{z}}$ takes place over the timescale of several hours, and therefore patterns in oxidation will reflect the photochemical environment integrated for several hours upwind. As at the suburban site, large changes in the abundance of $\mathrm{NO}_{2}$ result in smaller changes in $\mathrm{HNO}_{3}$. In this $\mathrm{NO}_{\mathrm{x}}$-limited environment, we would expect the rate of $\mathrm{NO}_{2}$ oxidation by $\mathrm{OH}$ to slow considerably on the weekend. The day-of-week pattern in $\mathrm{HNO}_{3}$, however, reflects the integral of the upwind production of $\mathrm{HNO}_{3}$, which is substantially faster in the urban environment. The timescale of $\mathrm{HNO}_{3}$ deposition and dilution need to be better quantified in the region to assess the relative roles of production and transport of $\mathrm{HNO}_{3}$ near the UC-BFRS. In our model, the absolute rates of organic nitrate production maximize near the same $\mathrm{NO}_{\mathrm{x}}$ concentrations as maximum $\mathrm{P}\left(\mathrm{O}_{3}\right)$. The middle panel of Fig. 14 confirms that total peroxy and alkyl nitrates are most rapidly produced upwind of the UC-BFRS on weekdays. The ratio of $\mathrm{NO}_{z}$ to $\mathrm{NO}_{x}$ varies by less than $10 \%$ during the week which, neglecting the influence of $\mathrm{NO}_{y}$ losses, indicates that along the entire trajectory from emission in Sacramento to observation in the UC-BFRS, the average rate of oxidation

\section{Weekend effent in \\ Scaramento: Part 2. Chemistry and transport \\ J. G. Murphy et al.}

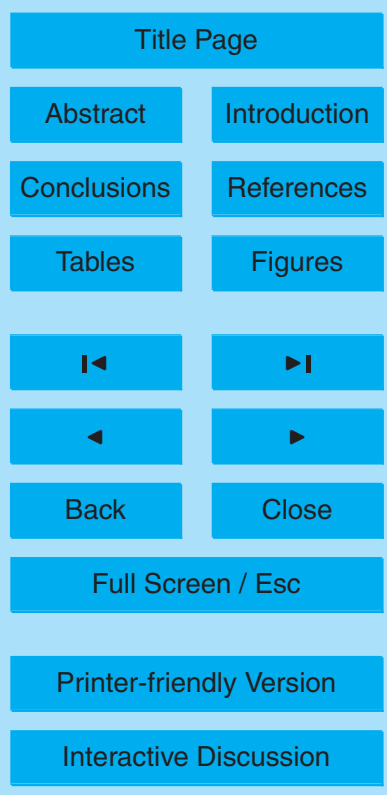


for a $\mathrm{NO}_{\mathrm{x}}$ molecule is the same. More rapid urban oxidation on weekends is balanced by slower oxidation in the remote regions and vice versa.

To summarize, observations of day-of-week patterns in $\mathrm{NO}_{y}$ and $\mathrm{VOC}$ species are all qualitatively and for the most part quantitatively consistent with analyses of $\mathrm{O}_{\mathrm{x}}$ and

$5 \Delta \mathrm{O}_{\mathrm{x}}$. The observations indicate that carryover from the previous day is an important control over $\mathrm{O}_{\mathrm{x}}$ in the region and that the transition between $\mathrm{NO}_{\mathrm{x}}$-limited and $\mathrm{NO}_{\mathrm{x}}-$ saturated ozone production occurs near or downwind of the surburban boundary of the Sacramento metropolitan area. Upwind of the suburbs, in the urban region ozone production at the surface is NOx-saturated.

\section{Conclusions}

The primary controls over day-of-week variations in $\mathrm{O}_{\mathrm{x}}$ mixing ratios in the Sacramento Valley and the downwind Mountain Counties are shown to be the $\mathrm{NO}_{x}$ dependence of ozone production and the carryover of ozone and/or its precursors from aloft, hypotheses \#6 and \#7. We show that ozone production upwind of the remote sites in the 15 Mountain Counties is $\mathrm{NO}_{\mathrm{x}}$-limited. $\mathrm{NO}_{\mathrm{x}}$ emissions from the Sacramento Valley are the main daytime source of $\mathrm{NO}_{x}$ in the Mountain Counties, therefore exceedances of the 8hour ozone standard at the remote sites can be immediately and effectively decreased by reductions in urban $\mathrm{NO}_{\mathrm{x}}$ emissions.

Comparison between observed rates of ozone accumulation in the Sacramento Val20 ley and calculated ozone production rates indicates that ozone production in the boundary layer upwind of sites in the Sacramento Valley is $\mathrm{NO}_{\mathrm{x}}$-saturated. Comparing observations on Sunday and Monday, when the effects of carryover are similar, it appears that a decrease in $\mathrm{NO}_{\mathrm{x}}$ concentrations of more than 35\% in the boundary layer results in an increase in odd oxygen accumulation of $7 \%$. If carryover of ozone and its pre25 cursors from aloft is largely due to return flow from the mountains east of the city, then reducing Sacramento urban $\mathrm{NO}_{\mathrm{x}}$ emissions will also reduce the contribution of carryover to the accumulation of high surface ozone the following day. To the extent that this

Weekend effent in

Scaramento: Part 2.

Chemistry and transport

J. G. Murphy et al.

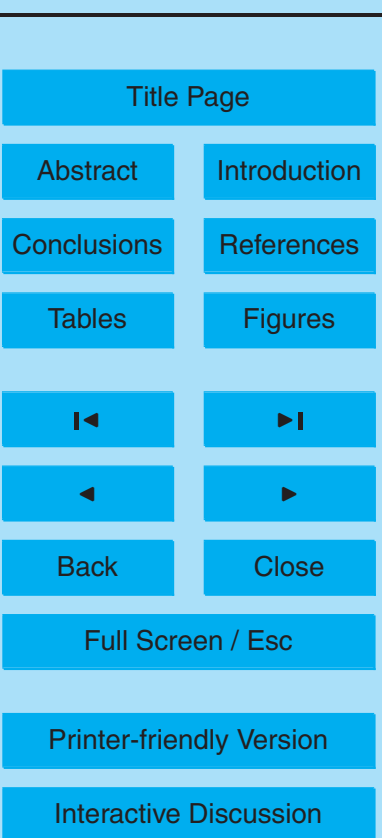


is the case, the Sacramento Valley can reduce its ozone problems with local controls. In this case, it would be appropriate to compare Sunday with Tues-Thurs, in which case both surface production and carryover have lower $\mathrm{NO}_{\mathrm{x}}$ availability. Observations suggest that reducing surface and carryover $\mathrm{NO}_{x}$ by $35 \%$ leads to comparable rates of $\mathrm{O}_{x}$

5 production. However, the high concentrations of ozone and precursors in the residual layer may also originate in other urban areas, in which case emission reductions in those air basins will also be required to reduce the carryover of ozone and/or precursors into Sacramento. This analysis suggests that $\mathrm{NO}_{\mathrm{x}}$ emission reductions of $50 \%$ or more are needed to guarantee lower rates of ozone production in the Sacramento 10 Valley.

Because the Sacramento Valley region is close to the crossover between $\mathrm{NO}_{\mathrm{x}}$-limited and VOC-limited ozone production, $\mathrm{NO}_{\mathrm{x}}$ emission reductions would initially be more effective if accompanied by reductions in VOC reactivity. This will be difficult to accomplish because biogenic emissions contribute significantly to VOC reactivity throughout 15 much of this region. For example, biogenics are responsible for at least $1 / 3$ of the total reactivity at Granite Bay (Cleary et al., 2005). From a regulatory perspective, it is important to point out that reductions in photochemical ozone production on the regional scale achieved through significant $\mathrm{NO}_{\mathrm{x}}$ emission reductions may not be evident at monitoring sites located close to $\mathrm{NO}_{x}$ sources, where the regional improvements will be locally counterbalanced by a decrease in ozone titration. As demonstrated in Murphy et al. (2006), local titration dominates the weekend effect in ozone observed at sites in the Sacramento Valley.

We also show that observations of day-of-week patterns can be used to test the mechanisms responsible for ozone production and distribution. Building on previous 25 research into the causes and implications of the weekend effect (e.g. Altshuler et al., 1995; Vukovich, 2000; Blanchard and Fairley, 2001; Fujita et al., 2003; Heuss et al., 2003; Pun et al., 2003; Yarwood et al., 2003; Jimenez et al., 2005) we suggest that some of the diagnostics we have described in this paper including day-of-week patterns in $\mathrm{NO}_{\mathrm{x}}, \mathrm{HNO}_{3}$, isoprene, and the rate of $\mathrm{O}_{\mathrm{x}}$ increase would be more rigorous tests of

Weekend effent in

Scaramento: Part 2. Chemistry and transport

J. G. Murphy et al.

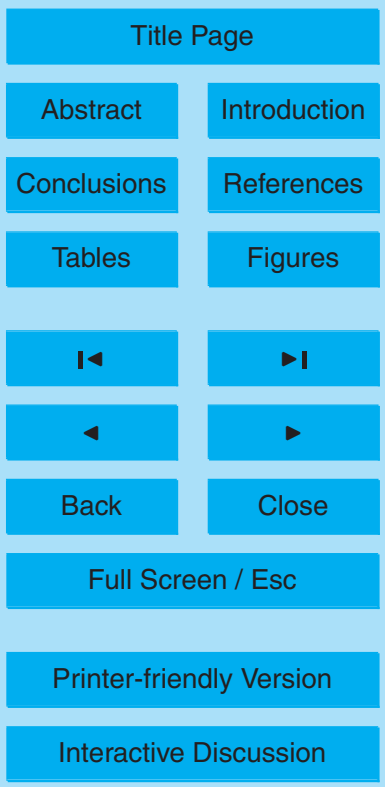


the parameterizations in regional air quality models than is their ability to reproduce any individual extreme ozone event. In particular, demonstrating that a model accurately describes day-of-week patterns of chemicals that are affected differently by chemistry and transport (e.g. $\mathrm{NO}_{2}, \mathrm{O}_{\mathrm{x}}$ and long-lived VOC) would be a strong confirmation that it 5 has the ability to accurately predict the change in ozone concentrations in response to a change in $\mathrm{NO}_{\mathrm{x}}$ emissions.

Acknowledgements. The analysis presented here was primarily supported by NSF ATM0138669. We gratefully acknowledge that support and the U.S. Department of Energy support for measurements at Granite Bay under contract AC03-76SF0009. Observations at the UC10 BFRS were supported by NSF ATM-0138669 (Cohen) and ATM-0443448 (Goldstein). D. B. Millet thanks DOE for a GREF fellowship. We thank M. McKay and G. Schade for assistance with meteorological, ozone, and VOC data from the UC-BFRS. Measurements at Big Hill were made in collaboration with the California Air Resources Board under Contract No. 01-327. We are grateful to the Eureka Union School District, Sierra Pacific Industries, and the United States

\section{References}

Altshuler, S. L., Arcado, T. D., and Lawson, D. R.: Weekday vs weekend ambient ozone concentrations - discussion and hypotheses with focus on Northern California, J. Air Waste Ma., 45, 967-972, 1995.

Blanchard, C. L. and Fairley, D.: Spatial mapping of VOC and $\mathrm{NO}_{\mathrm{x}}$-limitation of ozone formation in central California, Atmos. Env., 35, 3861-3873, 2001.

Blanchard, C. L. and Tanenbaum, S. J.: Differences between weekday and weekend air pollutant levels in southern California, J. Air Waste Ma., 53, 816-828, 2003.

Bossert, J. E.: An investigation of flow regimes affecting the Mexico City region, J. Appl. Meteorol., 36, 119-140, 1997.

California Air Resources Board: The Ozone Weekend Effect in California, pp, CARB Planning and Technical Support Division, Sacramento, 2003.

California Air Resources Board Air Quality Database, www.arb.ca.gov/aqd/aqdpage.

\section{Weekend effent in \\ Scaramento: Part 2. Chemistry and transport}

J. G. Murphy et al.

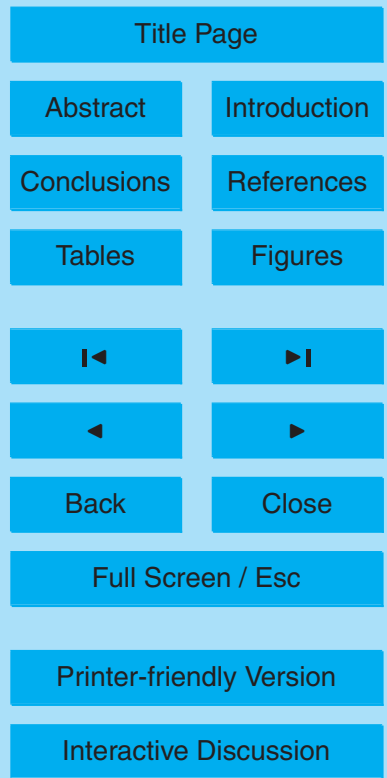


Carroll, J. J. and Dixon, A. J.: Regional scale transport over complex terrain, a case study: tracing the Sacramento plume in the Sierra Nevada of California, Atmos. Env., 36, 37453758, 2002.

Carslaw, D. C. and Beevers, S. D.: Development of an urban inventory for road transport emissions of $\mathrm{NO}_{2}$ and comparison with estimates derived from ambient measurements, Atmos. Env., 39, 2049-2059, 2005.

Cleary, P. A., Murphy, J. G., Wooldridge, P. J., Day, D. A., Millet, D. B., Goldstein, A. H., and Cohen, R. C.: Observations of total alkyl nitrates within the Sacramento urban plume, Atmos. Chem. Phys. Discuss., 5, 4801-4843, 2005.

10 Day, D. A.: Observations of $\mathrm{NO}_{2}$, total peroxynitrates, total alkyl nitrates, and $\mathrm{HNO}_{3}$ in the midSierras and Sacramento plume using Thermal Dissociation - Laser Induced Fluorescence, University of California, 207 pages, 2003.

Dillon, M. B.: The chemical evolution of the Sacramento urban plume, University of California, 205 pages, 2002.

Dillon, M. B., Lamanna, M. S., Schade, G. W., Goldstein, A. H., and Cohen, R. C.: Chemical evolution of the Sacramento urban plume: Transport and oxidation, J. Geophys. Res., 107, doi:10.1029/2001JD000969, 2002.

Fujita, E. M., Stockwell, W. R., Campbell, D. E., Keislar, R. E., and Lawson, D. R.: Evolution of the magnitude and spatial extent of the weekend ozone effect in California's South Coast Air

20 Basin, 1981-2000, J. Air Waste Ma., 53, 802-815, 2003.

Heuss, J. M., Kahlbaum, D. F., and Wolff, G. T.: Weekday/weekend ozone differences: What can we learn from them?, J. Air Waste Ma., 53, 772-788, 2003.

Jazcilevich, A. D., Garcia, A. R., and Ruiz-Suarez, L. G.: A study of air flow patterns affecting pollutant concentrations in the Central Region of Mexico, Atmos. Env., 37, 183-193, 2003.

Jimenez, P., Parra, R., Gasso, S., and Baldasano, J. M.: Modeling the ozone weekend effect in very complex terrains: a case study in the Northeastern Iberian Peninsula, Atmos. Env., 39, 429-444, 2005.

Kleinman, L. I., Daum, P. H., Lee, Y. N., Nunnermacker, L. J., Springston, S. R., WeinsteinLloyd, J., and Rudolph, J.: Sensitivity of ozone production rate to ozone precursors, Geophys. Res. Lett., 28, 2903-2906, 2001.

Kurpius, M. R. and Goldstein, A. H.: Gas-phase chemistry dominates $\mathrm{O}_{3}$ loss to a forest, implying a source of aerosols and hydroxyl radicals to the atmosphere, Geophys. Res. Lett., 108, doi:10.1029/2002GL016785, 2003.

\section{Weekend effent in \\ Scaramento: Part 2. \\ Chemistry and transport}

J. G. Murphy et al.

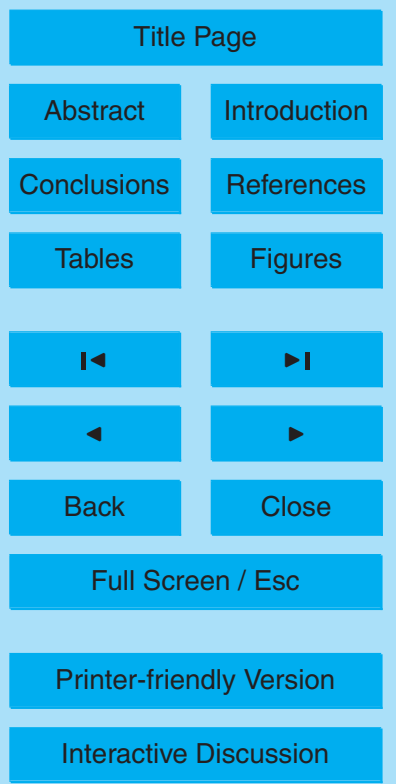


Lamanna, M. S. and Goldstein, A. H.: In situ measurements of $\mathrm{C}_{2}-\mathrm{C}_{10}$ volatile organic compounds above a Sierra Nevada ponderosa pine plantation, J. Geophys. Res., doi:10.1029/1999JD900289, 1999.

Lee, S. M., Fernando, H. J. S., Princevac, M., Zajic, D., Sinesi, M., McCulley, J. L., and Ander-

5 son, J.: Transport and diffusion of ozone in the nocturnal and morning planetary boundary layer of the Phoenix valley, Env. Tech., 3, 331-362, 2003.

Marr, L. C. and Harley, R. A.: Modeling the effect of weekday-weekend differences in motor vehicle emissions on photochemical air pollution in central California, Env. Sci. Tech., 36, 4099-4106, 2002.

10 Millet, D. B., Donahue, N. M., Pandis, S. N., Polidori, A., Stanier, C. O., Turpin, B. J., and Goldstein, A. H.: Atmospheric volatile organic compound measurements during the Pittsburgh Air Quality Study: Results, interpretation, and quantification of primary and secondary contributions, J. Geophys. Res., 110, doi:10.1029/2004JD004601, 2005.

Motallebi, N., Tran, H., Croes, B. E., and Larsen, L. C.: Day-of-week patterns of particulate 15 matter and its chemical components at selected sites in California, J. Air Waste Ma., 53, 876-888, 2003.

Murphy, J. G., Day, D. A., Cleary, P. A., Wooldridge, P. J., Millet, D. B., Goldstein, A. H., and Cohen, R. C.: The weekend effect within and downwind of Sacramento: Part 1. Observations of ozone, nitrogen oxides, and VOC reactivity, Atmos. Chem. Phys. Discuss., 6, 11427$11464,2006$.

Neu, U., Kunzle, T., and Wanner, H.: On The Relation Between Ozone Storage In The Residual Layer And Daily Variation In Near-Surface Ozone Concentration - A Case-Study, BoundaryLayer Meteorology, 69, 221-247, 1994.

Pun, B. K., Seigneur, C., and White, W.: Day-of-week behavior of atmospheric ozone in three US cities, J. Air Waste Ma., 53, 789-801, 2003.

Rubin, J. I., Kean, A. J., Harley, R. A., Millet, D. B., and Goldstein, A. H.: Temperature dependence of volatile organic compound evaporative emissions from motor vehicles, J. Geophys. Res., 111, doi:10.1029/2005JD006458, 2006.

Sander, S. P., Kurylo, J. M., Orkin, V. L., Golden, D. M., Huie, R. E., Finlayson-Pitts, B. J., Kolb, so C. E., Molina, M. J., Friedl, R. R., Ravishankara, A. R., and Moortgat, G. K.: NASA/JPL Data Evaluation, 2003.

Thornton, J. A., Wooldridge, P. J., Cohen, R. C., Martinez, M., Harder, H., Brune, W. H., Williams, E. J., Roberts, J. M., Fehsenfeld, F. C., Hall, S. R., Shetter, R. E., Wert, B. P.,

\section{Weekend effent in \\ Scaramento: Part 2. \\ Chemistry and transport}

J. G. Murphy et al.

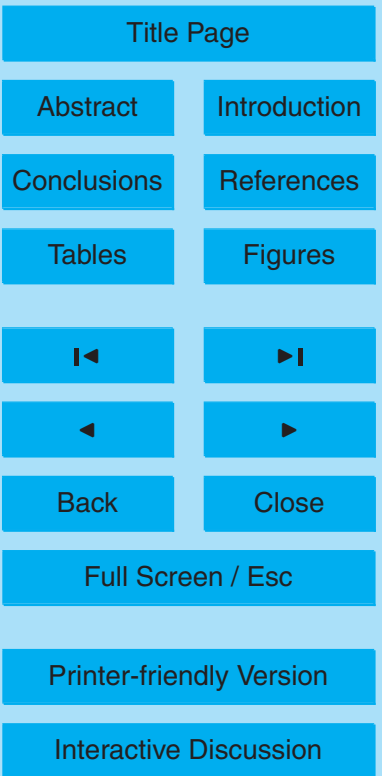


and Fried, A.: Ozone production rates as a function of $\mathrm{NO}_{\mathrm{x}}$ abundances and $\mathrm{HO}_{\mathrm{x}}$ production rates in the Nashville urban plume, J. Geophys. Res., 107, doi:10.1029/2001JD000932, 2002.

Tyndall, G. S., Cox, R. A., Granier, C., Lesclaux, R., Moortgat, G. K., Pilling, M. J., Ravis5 hankara, A. R., and Wallington, T. J.: Atmospheric chemistry of small organic peroxy radicals, J. Geophys. Res., 106, 12 157-12182, 2001.

Vukovich, F. M.: Weekday/weekend differences in $\mathrm{OH}$ reactivity with VOCs and $\mathrm{CO}$ in Baltimore, Maryland, J. Air Waste Ma., 50, 1843-1851, 2000.

Yarwood, G., Stoeckenius, T. E., Heiken, J. G., and Dunker, A. M.: Modeling weekday/weekend

10 Los Angeles region for 1997, J. Air Waste Ma., 53, 864-875, 2003.

Zhong, S. Y., Whiteman, C. D., and Bian, X. D.: Diurnal evolution of three-dimensional wind and temperature structure in California's Central Valley, J. Appl. Meteorol., 43, 1679-1699, 2004.

\section{ACPD}

6, 11971-12019, 2006

\section{Weekend effent in \\ Scaramento: Part 2. \\ Chemistry and transport}

J. G. Murphy et al.

\section{Title Page}

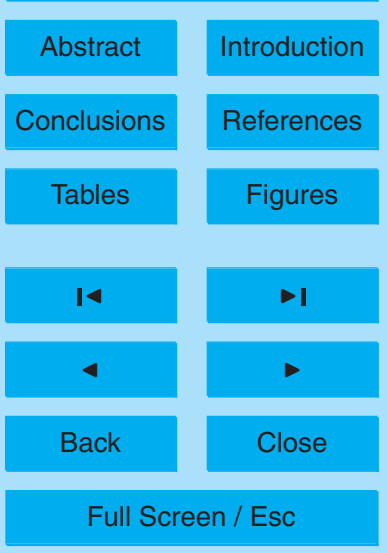

Printer-friendly Version

Interactive Discussion 


\section{ACPD}

6, 11971-12019, 2006

\section{Weekend effent in \\ Scaramento: Part 2. \\ Chemistry and \\ transport}

Table 1. Change in odd oxygen $\left(\Delta \mathrm{O}_{\mathrm{x}}\right.$ in ppb) between (09:00 and 13:00) for summer days (1998-2002) at sites in the Sacramento Valley. The final column was calculated by normalizing the basin-wide average for each day to the basin-wide weekly mean.

\begin{tabular}{cccccccc}
\hline Day & Folsom & T Street & Roseville & Del Paso & N High. & Elk Grove & $\begin{array}{c}\text { Normalized } \\
\text { Average }\end{array}$ \\
\hline Sun & 24.3 & 23.0 & 24.7 & 26.1 & 22.1 & 20.5 & 0.99 \\
Mon & 22.4 & 19.8 & 23.2 & 23.9 & 21.0 & 20.4 & 0.92 \\
TWT & 23.9 & 22.2 & 25.6 & 25.0 & 22.3 & 22.0 & 0.99 \\
Fri & 25.5 & 22.0 & 26.3 & 25.6 & 23.6 & 20.7 & 1.01 \\
Sat & 26.3 & 25.2 & 26.4 & 27.6 & 24.8 & 22.5 & 1.08 \\
\hline
\end{tabular}

J. G. Murphy et al.

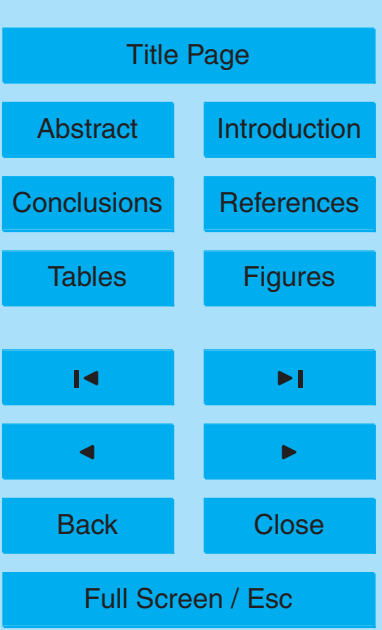

Printer-friendly Version

Interactive Discussion 


\section{ACPD}

6, 11971-12019, 2006

\section{Weekend effent in \\ Scaramento: Part 2. \\ Chemistry and \\ transport}

Table 2. Average concentration of $\mathrm{NO}_{\mathrm{x}}(\mathrm{ppb})$ between (09:00 and 13:00) for summer days (1998-2002) at sites in the Sacramento Valley. The final column was calculated by normalizing the basin-wide average for each day to the basin-wide weekly mean.

\begin{tabular}{cccccccc}
\hline Day & Folsom & T Street & Roseville & Del Paso & N High. & Elk Grove & $\begin{array}{c}\text { Normalized } \\
\text { Average }\end{array}$ \\
\hline Sun & 3.8 & 13.2 & 9.3 & 7.6 & 6.0 & 4.4 & 0.65 \\
Mon & 7.8 & 21.8 & 16.5 & 13.4 & 10.7 & 7.3 & 1.13 \\
TWT & 8.2 & 21.0 & 16.9 & 14.4 & 12.5 & 7.9 & 1.18 \\
Fri & 8.3 & 21.8 & 17.2 & 14.4 & 12.8 & 8.0 & 1.21 \\
Sat & 5.6 & 15.2 & 12.1 & 10.1 & 8.9 & 5.5 & 0.84 \\
\hline
\end{tabular}

J. G. Murphy et al.

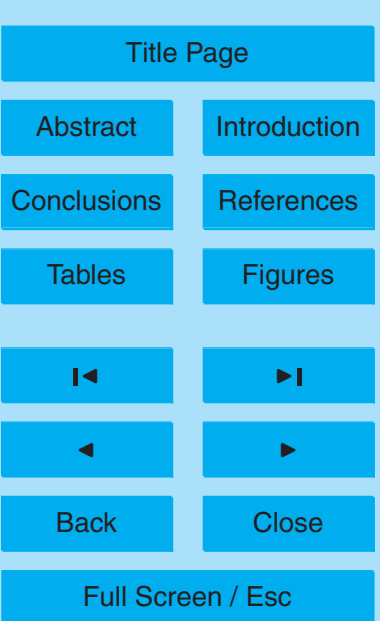

Printer-friendly Version

Interactive Discussion 


\section{ACPD}

6, 11971-12019, 2006

\section{Weekend effent in \\ Scaramento: Part 2. \\ Chemistry and \\ transport}

Table 3. Change in odd oxygen $\left(\Delta \mathrm{O}_{3}\right.$ in ppb) during the $4 \mathrm{~h}$ period chosen to coincide with the urban plume for summer days (1998-2002) at sites in the Mountain Counties. The final column was calculated by normalizing the basin-wide average for each day to the basin-wide weekly mean.

\begin{tabular}{cccccccc}
\hline Day & Cool & Colfax & W. Cloud & Placerville & UC-BFRS & Jackson & $\begin{array}{c}\text { Normalized } \\
\text { Average }\end{array}$ \\
\hline Sun & 11.7 & 8.1 & 3.8 & 9.3 & 7.4 & 12.3 & 0.86 \\
Mon & 13.0 & 7.2 & 6.0 & 10.4 & 10.5 & 13.5 & 0.99 \\
TWT & 14.9 & 9.3 & 8.3 & 10.7 & 10.4 & 15.4 & 1.13 \\
Fri & 14.7 & 9.0 & 6.7 & 11.2 & 8.5 & 14.8 & 1.07 \\
Sat & 14.2 & 7.7 & 4.9 & 9.8 & 8.1 & 14.1 & 0.95 \\
\hline
\end{tabular}

J. G. Murphy et al.

Title Page

Abstract Introduction

Conclusions References

Tables Figures

14

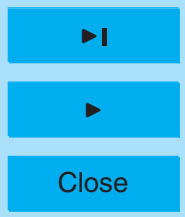

Back

Full Screen / Esc

Printer-friendly Version

Interactive Discussion 


\section{ACPD}

6, 11971-12019, 2006

\section{Weekend effent in}

Scaramento: Part 2.

Chemistry and

transport

Table 4. Rate Constants and Other Values Used to Model $\mathrm{HO}_{\mathrm{x}}$ and $\mathrm{P}\left(\mathrm{O}_{3}\right)$.

\begin{tabular}{ccl}
\hline Parameter & Value & Source \\
\hline $\mathrm{P}\left(\mathrm{HO}_{\mathrm{x}}\right)$ & $2.25 \mathrm{ppb} / \mathrm{hr}$ & Dillon (2002) \\
$\mathrm{k}_{1}[\mathrm{VOC}]$ & $5.8 \mathrm{~s}^{-1}$ & Millet et al. (2005) \\
$\alpha$ & 0.04 & Cleary et al. (2005) \\
{$\left[\mathrm{NO}_{2}\right] /[\mathrm{NO}]$} & 4 & daytime observations \\
$\mathrm{k}_{4}$ & $1.1 \times 10^{-11} \mathrm{~s} \mathrm{~cm}^{3} \mathrm{molec}^{-1}$ & Sander et al. (2003) \\
$\mathrm{k}_{2 \text { eff }}$ & $8 \times 10^{-12} \mathrm{~s} \mathrm{~cm}^{3} \mathrm{molec}^{-1}$ & Tyndall et al. (2001) \\
$\mathrm{k}_{5}$ & $5.0 \times 10^{-12} \mathrm{~s} \mathrm{~cm}^{3} \mathrm{molec}^{-1}$ & Tyndall et al. (2001); Sander et al. (2003) \\
& &
\end{tabular}

J. G. Murphy et al.

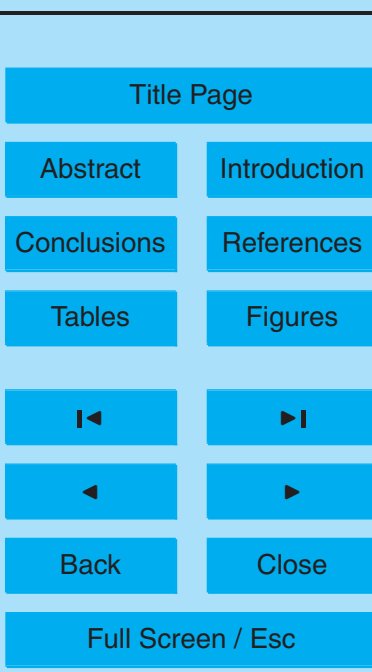

Printer-friendly Version

Interactive Discussion 


\section{ACPD}

6, 11971-12019, 2006

\section{Weekend effent in \\ Scaramento: Part 2. \\ Chemistry and \\ transport}

Table 5. Qualitative patterns in $\mathrm{NO}_{\mathrm{x}}$ concentrations and ozone production in the boundary layer $(\mathrm{BL})$ and residual layer $(\mathrm{RL})$ and the predicted impact on $\Delta \mathrm{O}_{\mathrm{x}}$ compared to observations in Sacramento Valley (observed $\Delta \mathrm{O}_{\mathrm{x}}$ is final column from Table 1).

\begin{tabular}{ccccccc}
\hline Day & $\mathrm{BL} \mathrm{NO}_{x}$ & $\mathrm{BLP}\left(\mathrm{O}_{3}\right)$ & $\mathrm{RL} \mathrm{NO}$ & $\mathrm{RL} \mathrm{P}\left(\mathrm{O}_{3}\right)$ & predicted $\Delta \mathrm{O}_{x}$ & observed $\Delta \mathrm{O}_{\mathrm{x}}$ \\
\hline Sun & Low & High & Low & Low & Medium & 0.99 \\
Mon & High & Low & Low & Low & Low & 0.92 \\
TWT & High & Low & High & High & Medium & 0.99 \\
Fri & High & Low & High & High & Medium & 1.01 \\
Sat & Low & High & High & High & High & 1.08 \\
\hline
\end{tabular}

J. G. Murphy et al.

Title Page

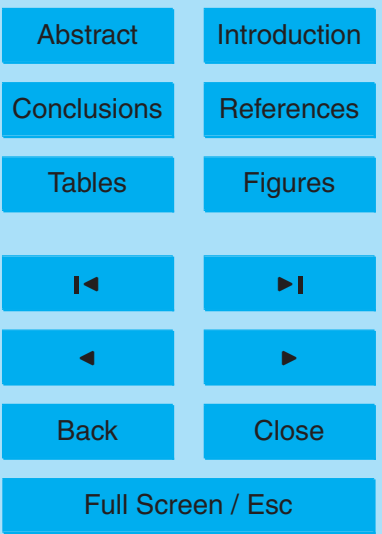

Printer-friendly Version

Interactive Discussion 


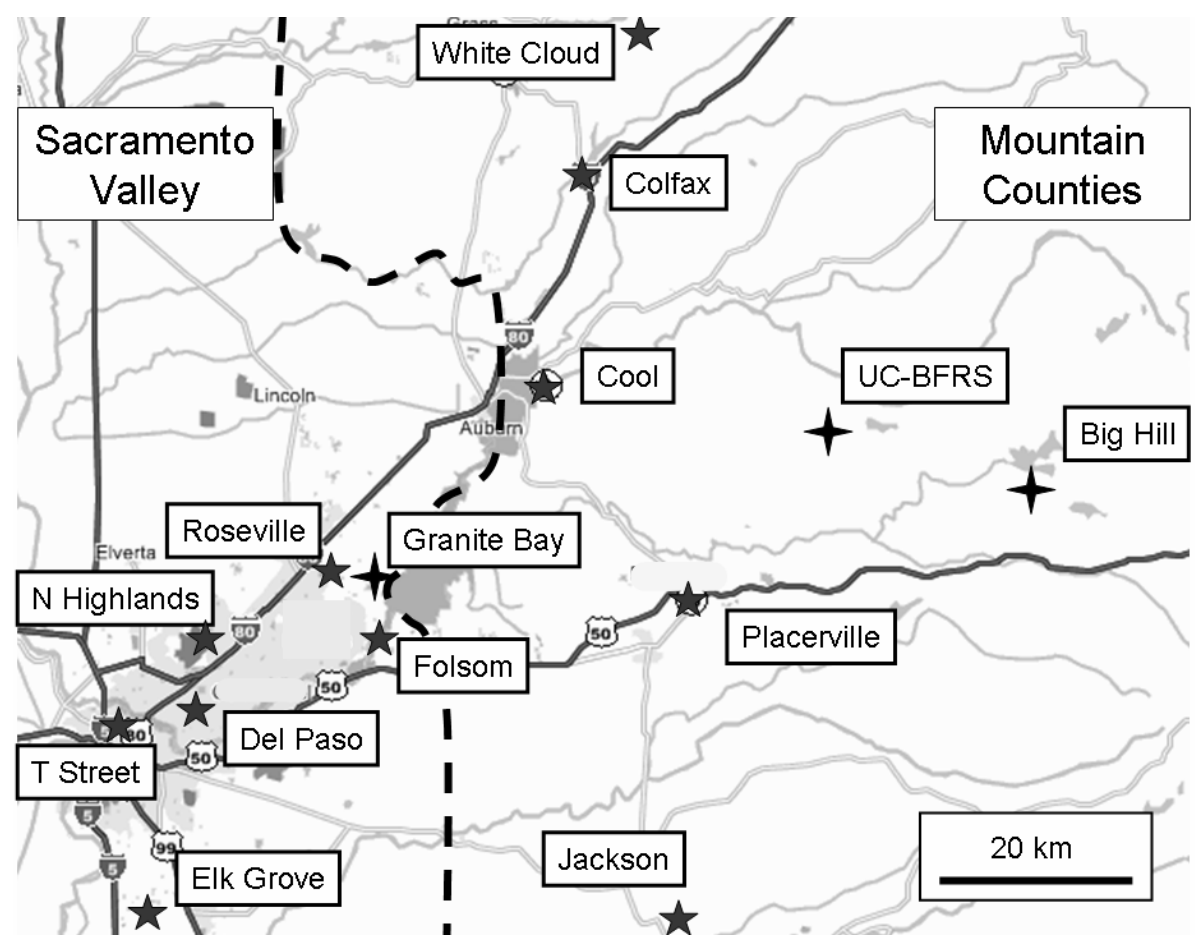

Fig. 1. The location of the monitoring sites in the Sacramento Valley and Mountain Counties (separated by the dashed line) used in this analysis. The light grey shaded area represents to Sacramento municipal area, and the dark grey area to its northeast is a California State Park. Routine monitoring sites maintained by CARB are denoted with ( $\star$ ) and sites run by UC Berkeley researchers are marked with ( + ).

\section{6, 11971-12019, 2006}

\section{Weekend effent in Scaramento: Part 2. Chemistry and transport}

J. G. Murphy et al.

\section{Title Page}

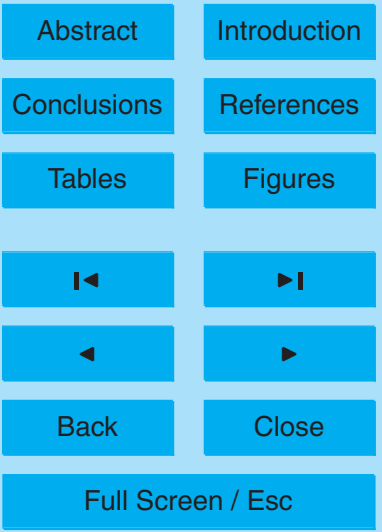

Printer-friendly Version

Interactive Discussion 


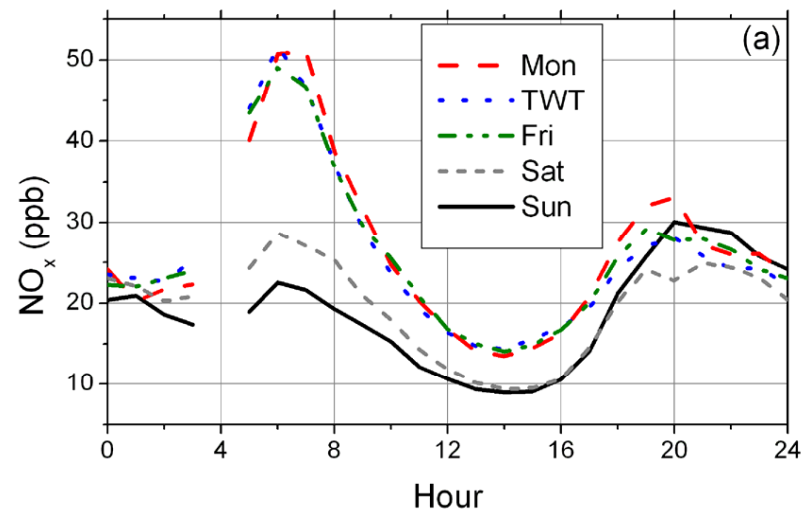

\section{ACPD}

6, 11971-12019, 2006

\section{Weekend effent in}

Scaramento: Part 2.

Chemistry and

transport

J. G. Murphy et al.

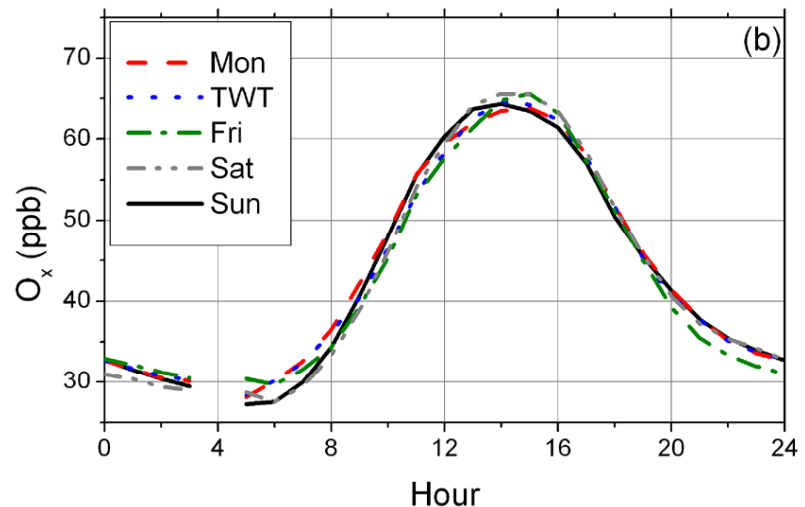

Title Page

Abstract

Introduction

Conclusions

References

Tables

Figures

14

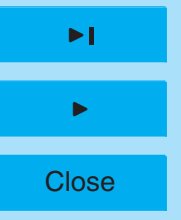

Back

Full Screen / Esc

Fig. 2. Diurnal trends in (a) $\mathrm{NO}_{x}$ and (b) $\mathrm{O}_{x}$ at T Street (summers 1998-2002).

Printer-friendly Version

Interactive Discussion 


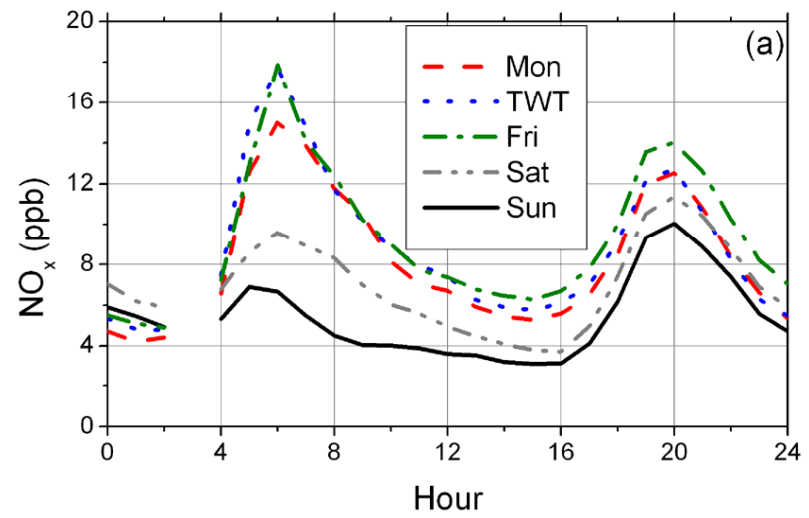

\section{ACPD}

6, 11971-12019, 2006

\section{Weekend effent in \\ Scaramento: Part 2. \\ Chemistry and \\ transport}

J. G. Murphy et al.

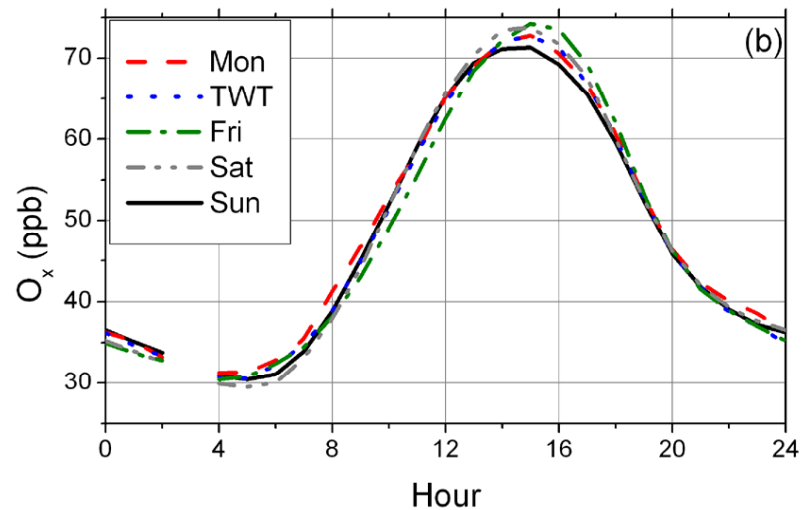

Title Page

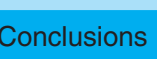

Introduction

Conclusions

References

Tables

Figures

14

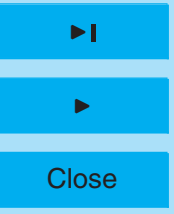

Back

Full Screen / Esc

Fig. 3. Diurnal trends in (a) $\mathrm{O}_{x}$ and (b) $\mathrm{NO}_{x}$ at Folsom (summers 1998-2002).

Printer-friendly Version

Interactive Discussion 


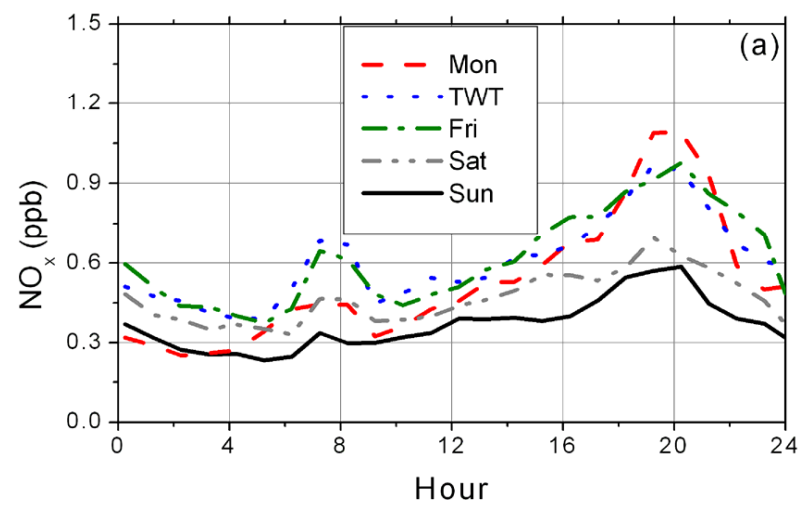

\section{ACPD}

6, 11971-12019, 2006

\section{Weekend effent in \\ Scaramento: Part 2. \\ Chemistry and transport}

J. G. Murphy et al.

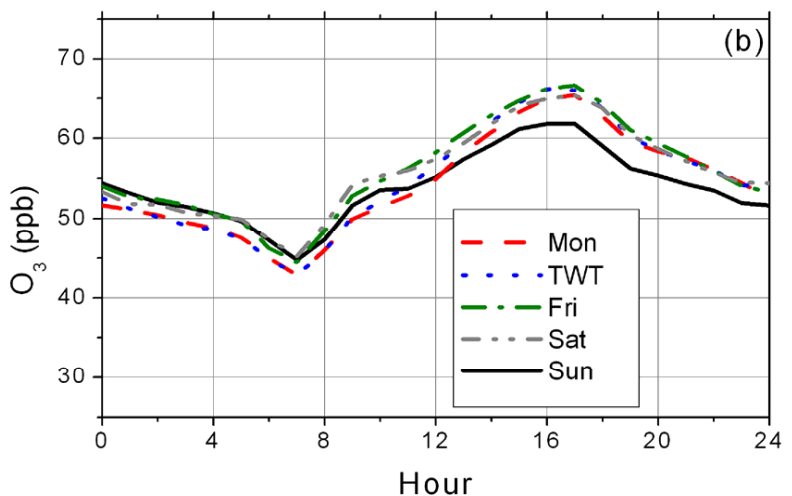

Title Page

Abstract

Introduction

Conclusions

References

Tables

Figures

14

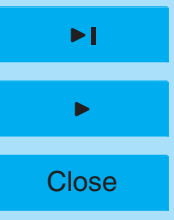

Back

Full Screen / Esc

Fig. 4. Diurnal trends in (a) $\mathrm{NO}_{x}$ (summer 2001) and (b) $\mathrm{O}_{3}$ (summers 1998-2002) at UCBFRS.

Printer-friendly Version

Interactive Discussion 


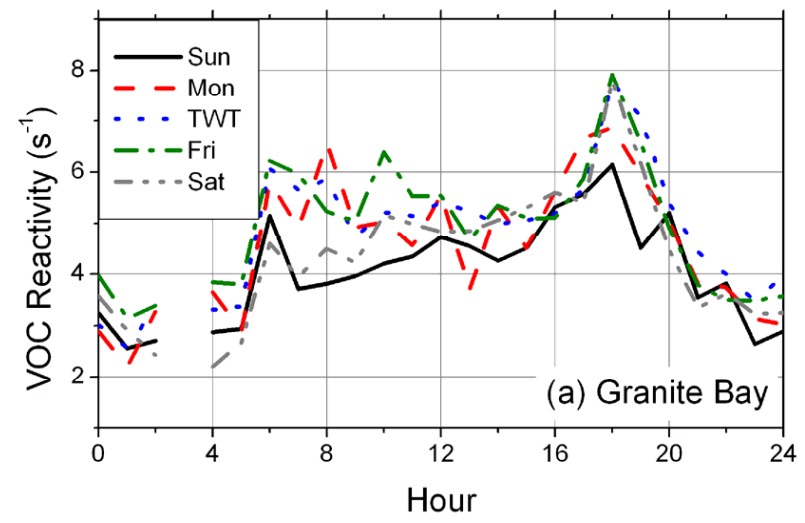

\section{ACPD}

6, 11971-12019, 2006

\section{Weekend effent in \\ Scaramento: Part 2. \\ Chemistry and \\ transport}

J. G. Murphy et al.

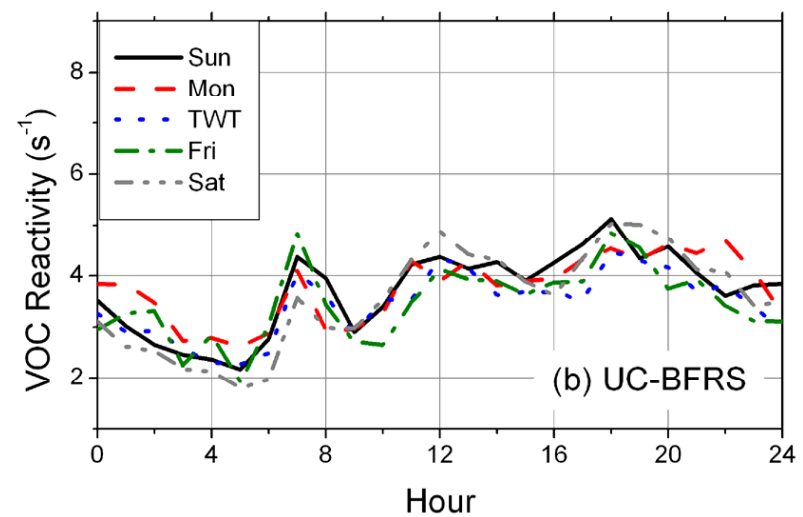

Title Page

Abstract

Introduction

Conclusions

References

Tables

Figures

14

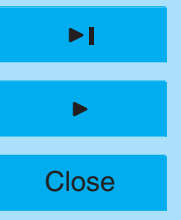

Back

Full Screen / Esc

Fig. 5. Diurnal trends in VOC reactivity (July-September 2001) at (a) Granite Bay and (b) UC-BFRS.

Printer-friendly Version

Interactive Discussion 


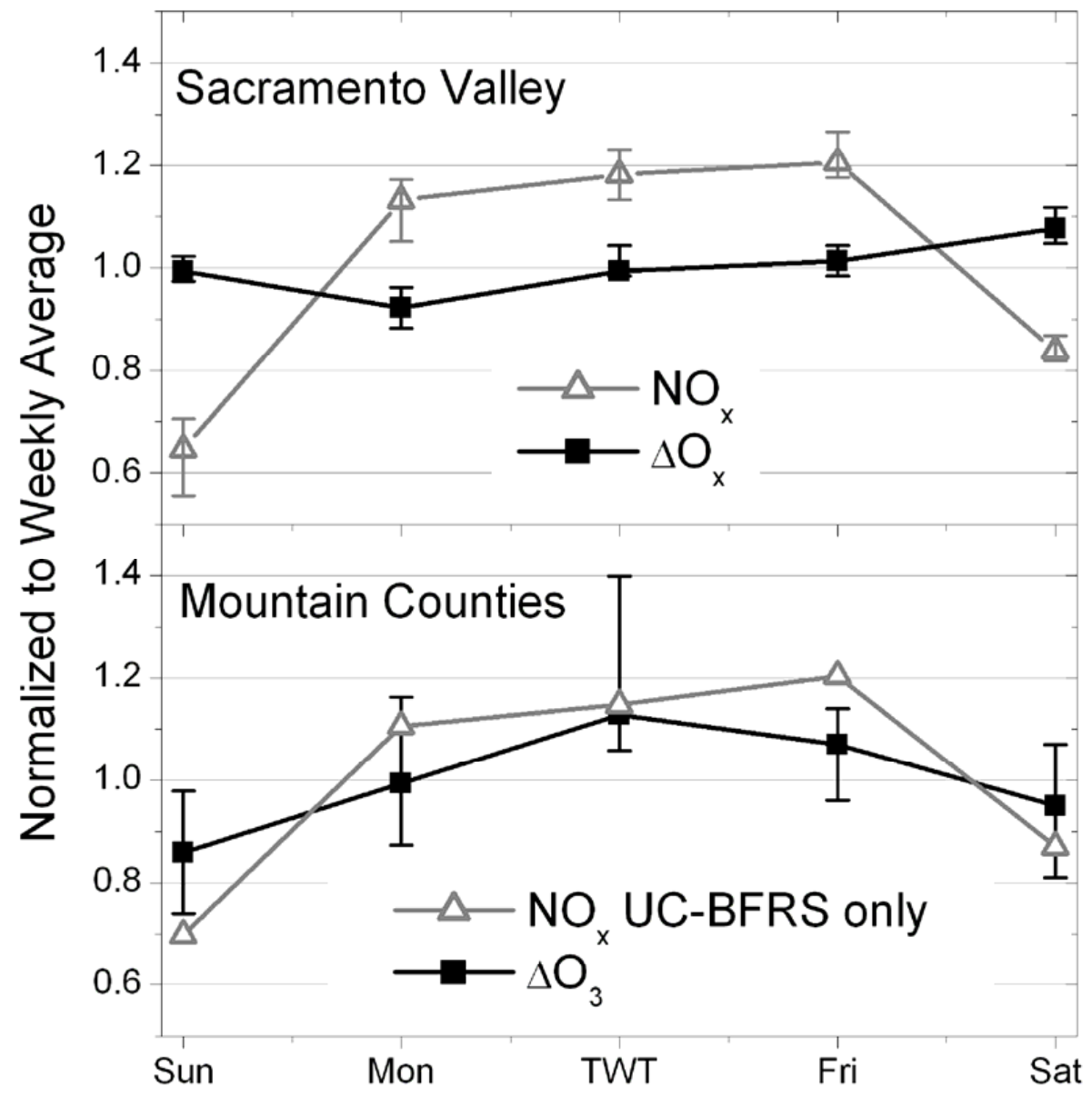

ACPD

6, 11971-12019, 2006

Weekend effent in Scaramento: Part 2. Chemistry and transport

J. G. Murphy et al.

\section{Title Page}

Abstract

Introduction

Conclusions

References

Tables

Figures

14

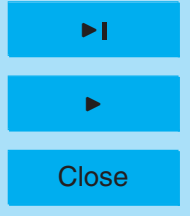

Back

Full Screen / Esc

Printer-friendly Version

Interactive Discussion 


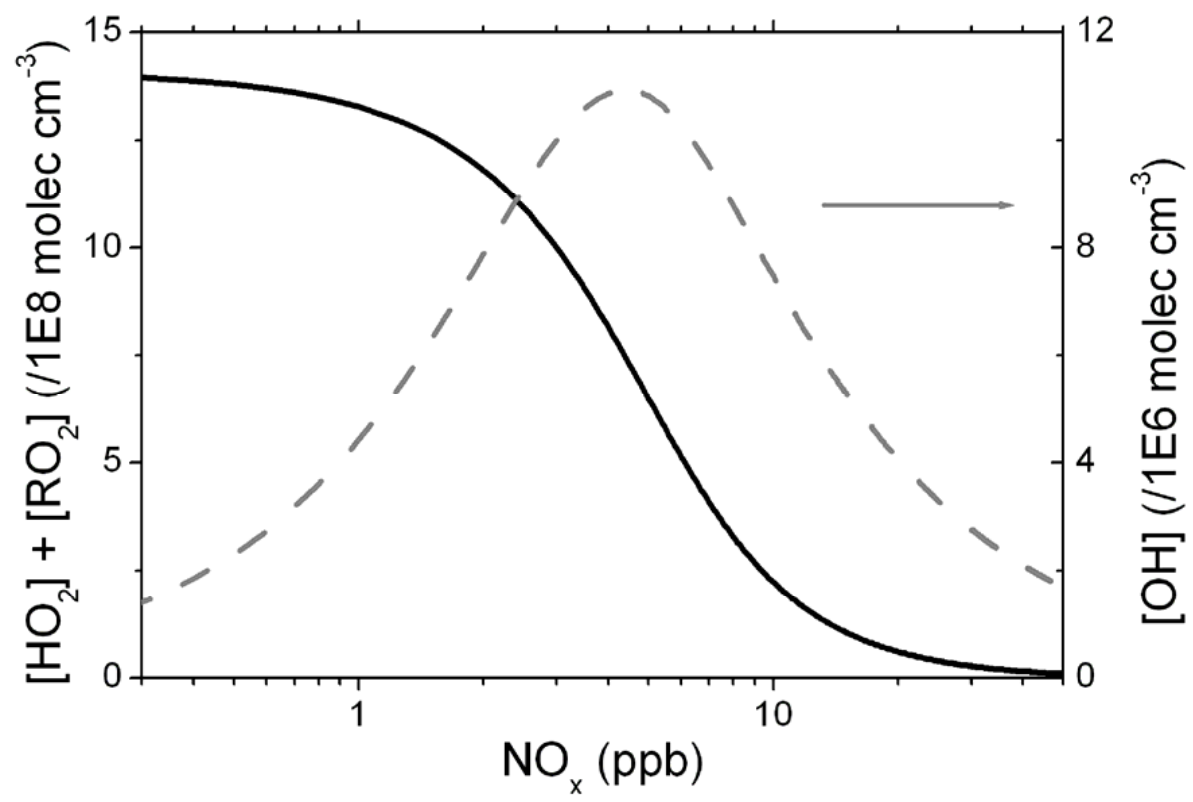

Fig. 7. $\mathrm{NO}_{x}$ dependence of the concentration of odd hydrogen radicals, $[\mathrm{OH}](---)$ in units of $\left(10^{6}\right.$ molecules $\left.\mathrm{cm}^{-3}\right)$ and $\left[\mathrm{HO}_{2}+\mathrm{RO}_{2}\right](-)$ in units of $\left(10^{8}\right.$ molecules $\left.\mathrm{cm}^{-3}\right)$.

\section{ACPD}

6, 11971-12019, 2006

\section{Weekend effent in Scaramento: Part 2. Chemistry and transport \\ J. G. Murphy et al.}

\section{Title Page}

\section{Abstract} Introduction

Conclusions

References

Tables

Figures

14

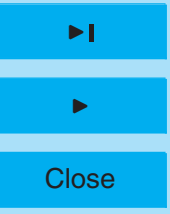

Back

Full Screen / Esc

Printer-friendly Version

Interactive Discussion 


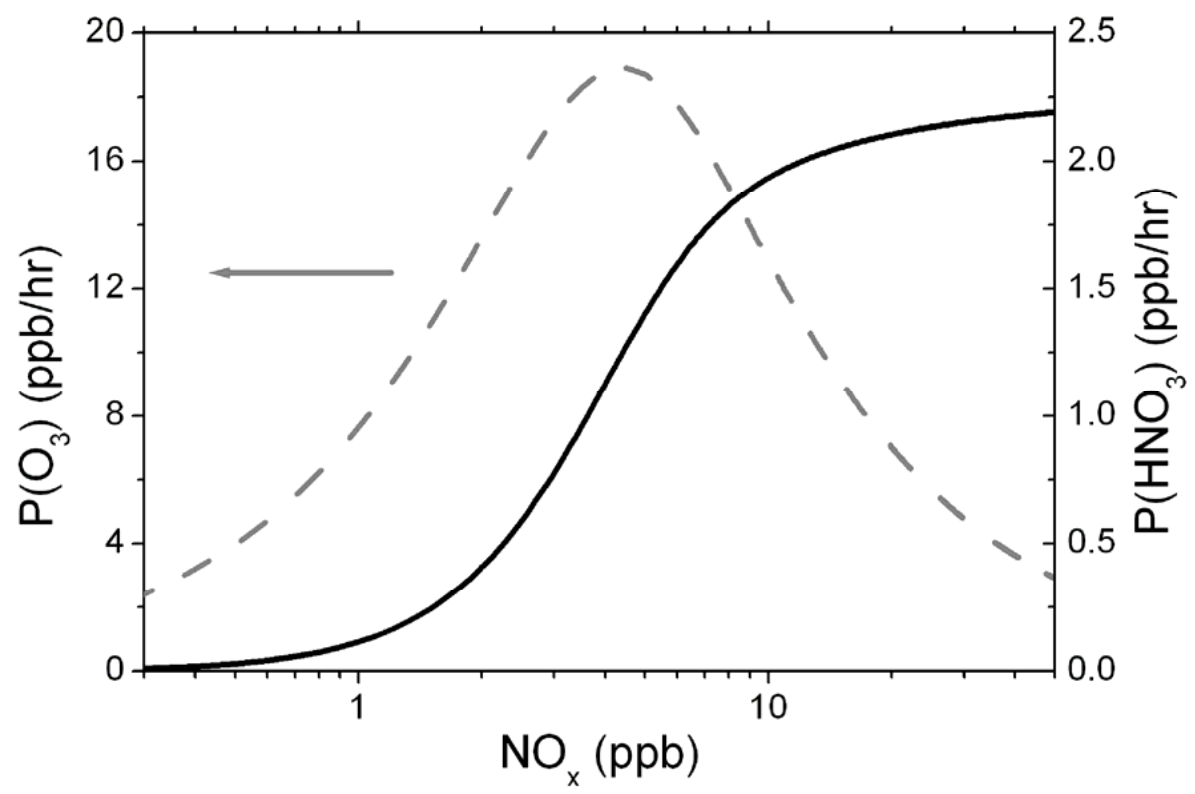

Fig. 8. $\mathrm{NO}_{\mathrm{x}}$ dependence of the instantaneous production rates of ozone, $\mathrm{P}\left(\mathrm{O}_{3}\right)(---)$ and nitric acid $\mathrm{P}\left(\mathrm{HNO}_{3}\right)(-)$.

\section{ACPD}

6, 11971-12019, 2006

\section{Weekend effent in Scaramento: Part 2. Chemistry and transport \\ J. G. Murphy et al.}

Title Page

Abstract

Introduction

Conclusions

References

Tables

Figures

14

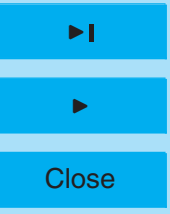

Back

Full Screen / Esc

Printer-friendly Version

Interactive Discussion 


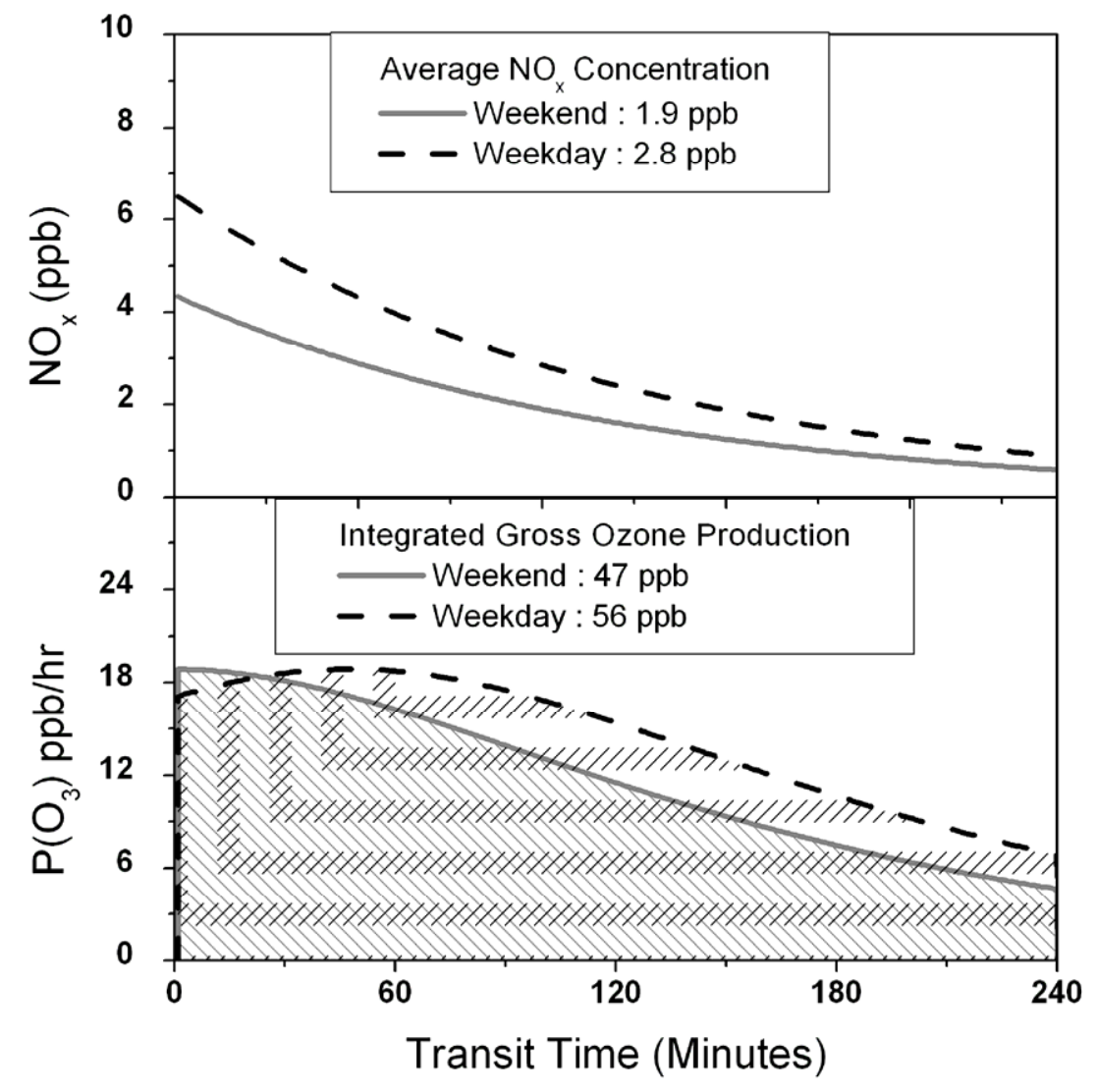

Fig. 9. Visual depiction of the range of $\mathrm{NO}_{\mathrm{x}}$ conditions under which ozone production occurs for an airmass in transit from Granite Bay to UC-BFRS. Weekends (-) and weekdays (- - -) are shown separately.

\section{ACPD}

6, 11971-12019, 2006

\section{Weekend effent in \\ Scaramento: Part 2. \\ Chemistry and \\ transport}

J. G. Murphy et al.

Title Page

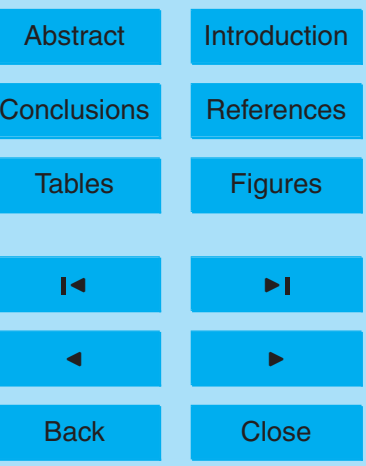

Full Screen / Esc

Printer-friendly Version

Interactive Discussion 


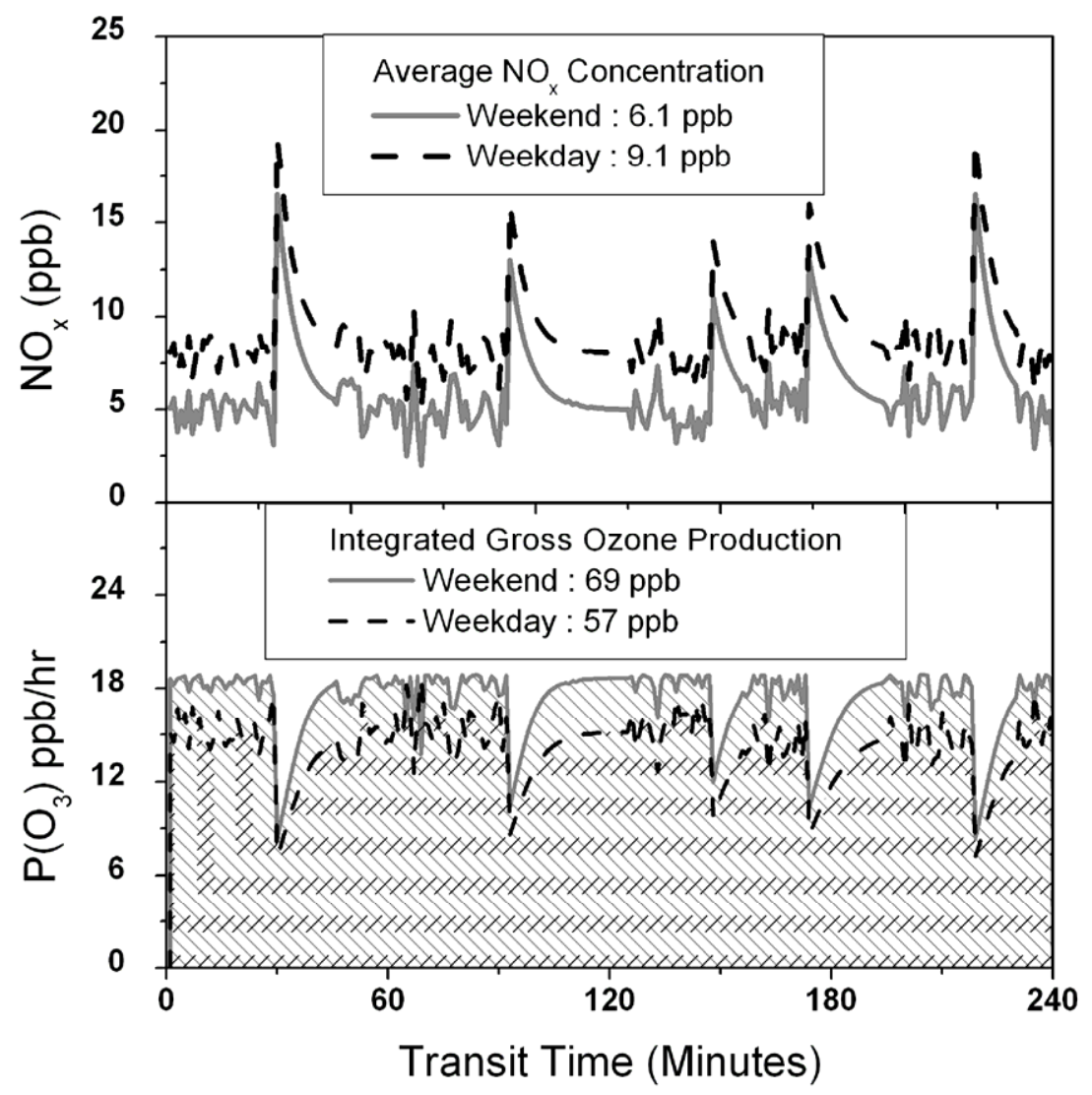

Fig. 10. Visual depiction of the range of $\mathrm{NO}_{x}$ conditions under which ozone production occurs upwind of a hypothetical site in the Sacramento Valley. Weekends (-) and weekdays (- - -) are shown separately.

\section{ACPD}

6, 11971-12019, 2006

\section{Weekend effent in \\ Scaramento: Part 2. \\ Chemistry and \\ transport}

J. G. Murphy et al.

\section{Title Page}

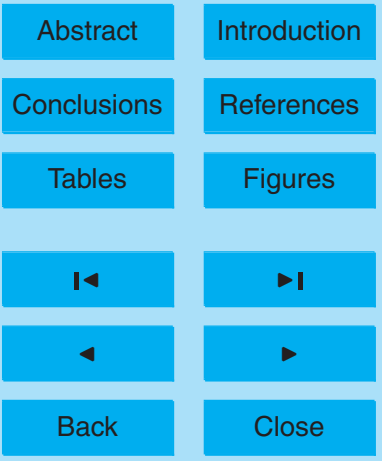

Full Screen / Esc

Printer-friendly Version

Interactive Discussion 


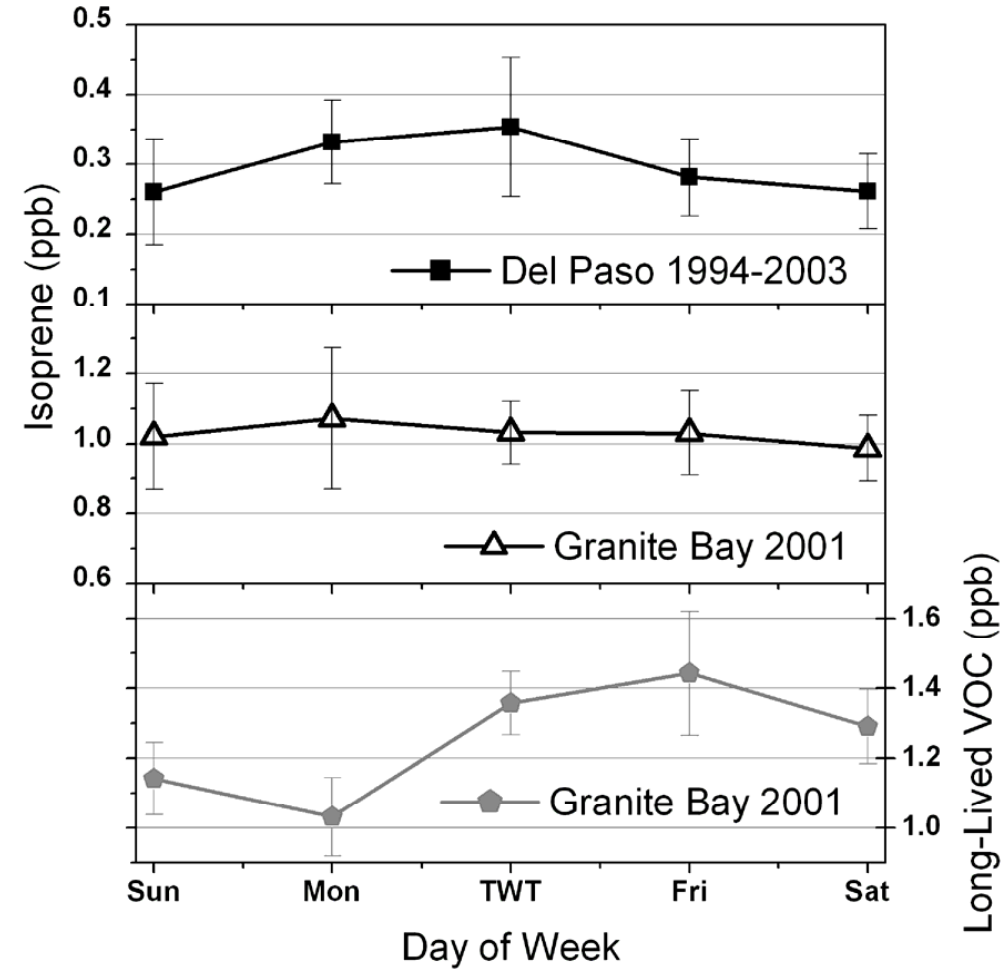

Fig. 11. Speciated VOC observations from sites in the Sacramento Valley. The top panel shows measurements of isoprene made by the Del Paso PAMS site between 12:00 and 15:00 from the summers of 1994-2003. The middle panel shows measurements of isoprene by GCMS at Granite Bay between 10:00 and 18:00 in the summer of 2001. The bottom panel shows Granite Bay measurements for the same time period of long-lived anthropogenic VOC (benzene + butane + isobutene + pentane + isopentane). Error bars are twice the standard deviation of the mean.
Weekend effent in

Scaramento: Part 2.

Chemistry and

transport

J. G. Murphy et al.

Title Page

Abstract

Introduction

Conclusions

References

Tables

Figures

14

$>1$

4

Back

Close

Printer-friendly Version

Interactive Discussion 


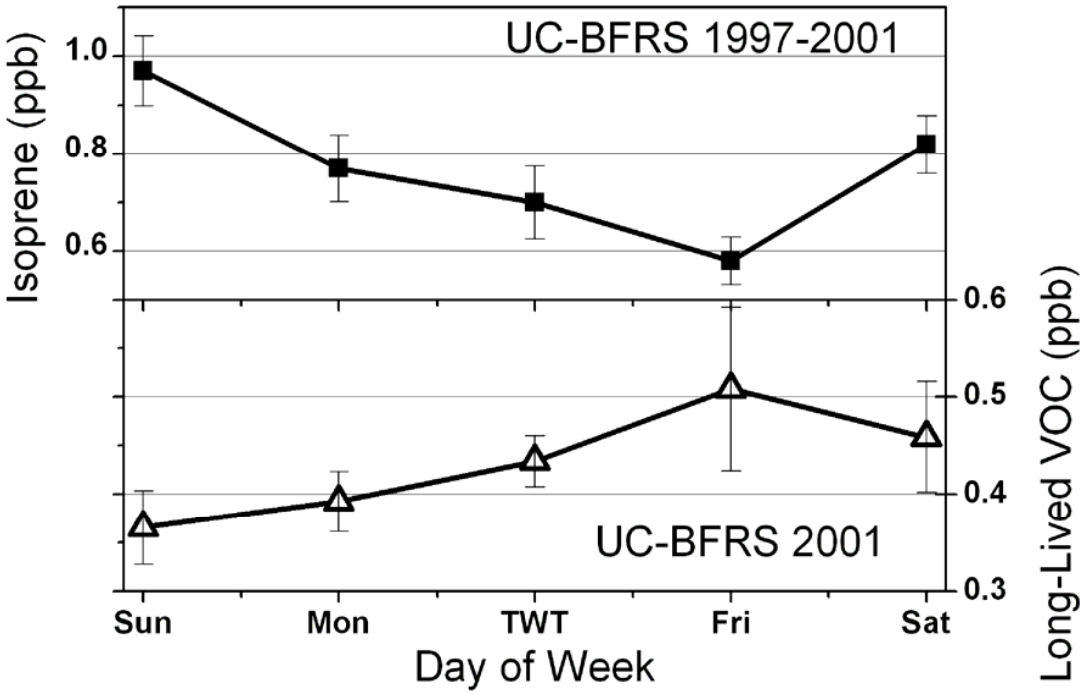

Fig. 12. Speciated VOC observations from UC-BFRS between 12:00 and 20:00. The top panel shows measurements of isoprene made at UC-BFRS from the summers of 1997-2001. The bottom panel shows UC-BFRS measurements in 2001 of long-lived anthropogenic VOC (benzene + butane + isobutene + pentane + isopentane).

6, 11971-12019, 2006

\section{Weekend effent in}

Scaramento: Part 2.

Chemistry and

transport

J. G. Murphy et al.

\section{Title Page}

Abstract

Conclusions

Tables

14

4

Back
Introduction

References

Figures

$\rightarrow$

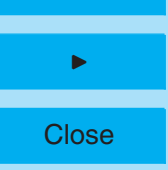

Full Screen / Esc

Printer-friendly Version 


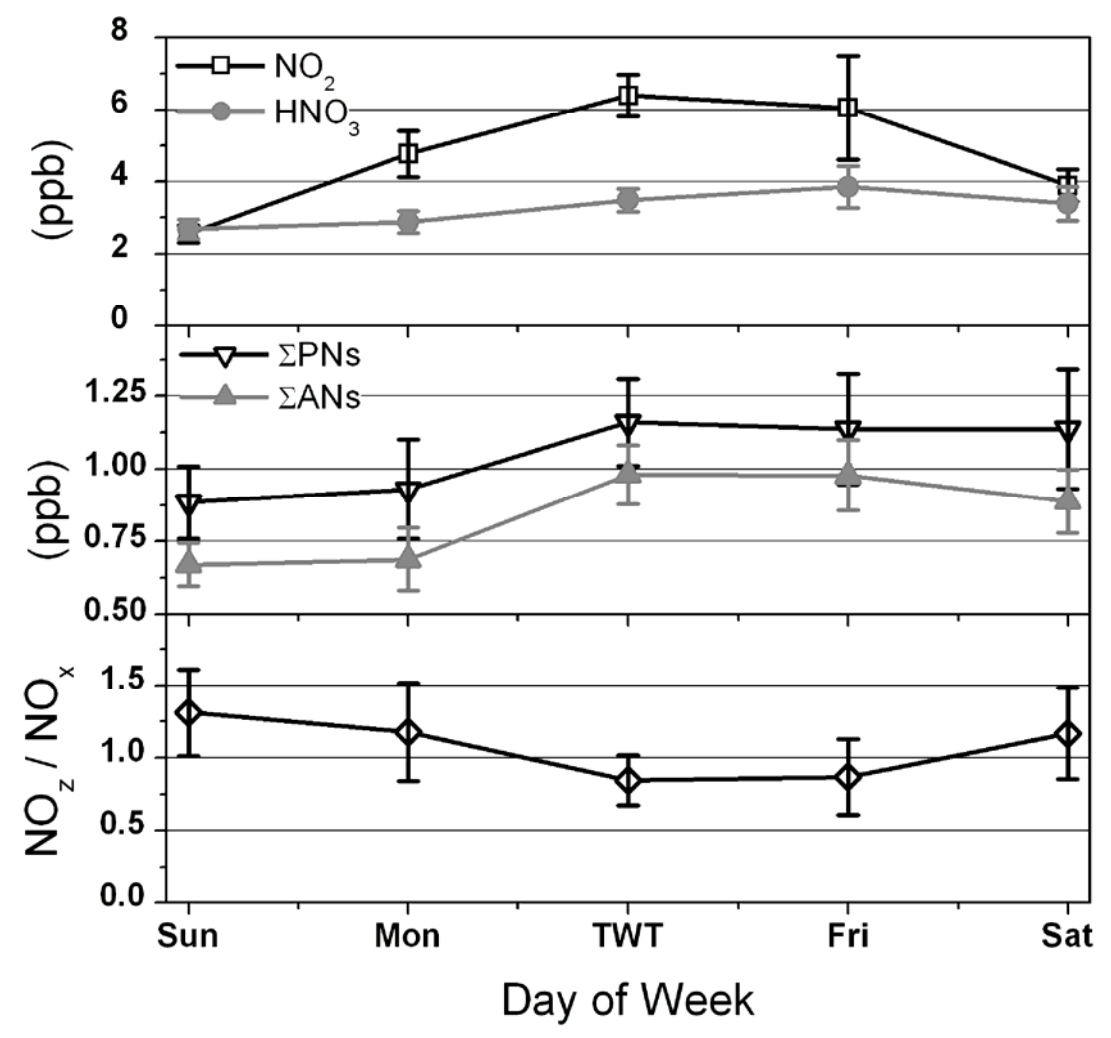

Fig. 13. Speciated $\mathrm{NO}_{\mathrm{yi}}$ observations from Granite Bay all made between 10:00 and 18:00 during the summer of 2001. The top panel shows measurements $\mathrm{NO}_{2}$ and $\mathrm{HNO}_{3}$. The middle panel shows measurements of sum peroxy nitrates and sum alkyl nitrates. In the bottom panel, the diamonds correspond to the left axis and show the ratio of $\mathrm{NO}_{z}$ to $\mathrm{NO}_{x}$ in the airmass $\left(\mathrm{NO}_{\mathrm{Z}} \equiv \Sigma \mathrm{PNs}+\Sigma \mathrm{ANs}+\mathrm{HNO}_{3}\right)$. Error bars are twice the standard deviation of the mean.

\section{ACPD}

6, 11971-12019, 2006

Weekend effent in

Scaramento: Part 2.

Chemistry and

transport

J. G. Murphy et al.

Title Page

Abstract

Introduction

Conclusions

References

Tables

Figures

14

$>1$

4

Back

Close

Printer-friendly Version

Interactive Discussion 


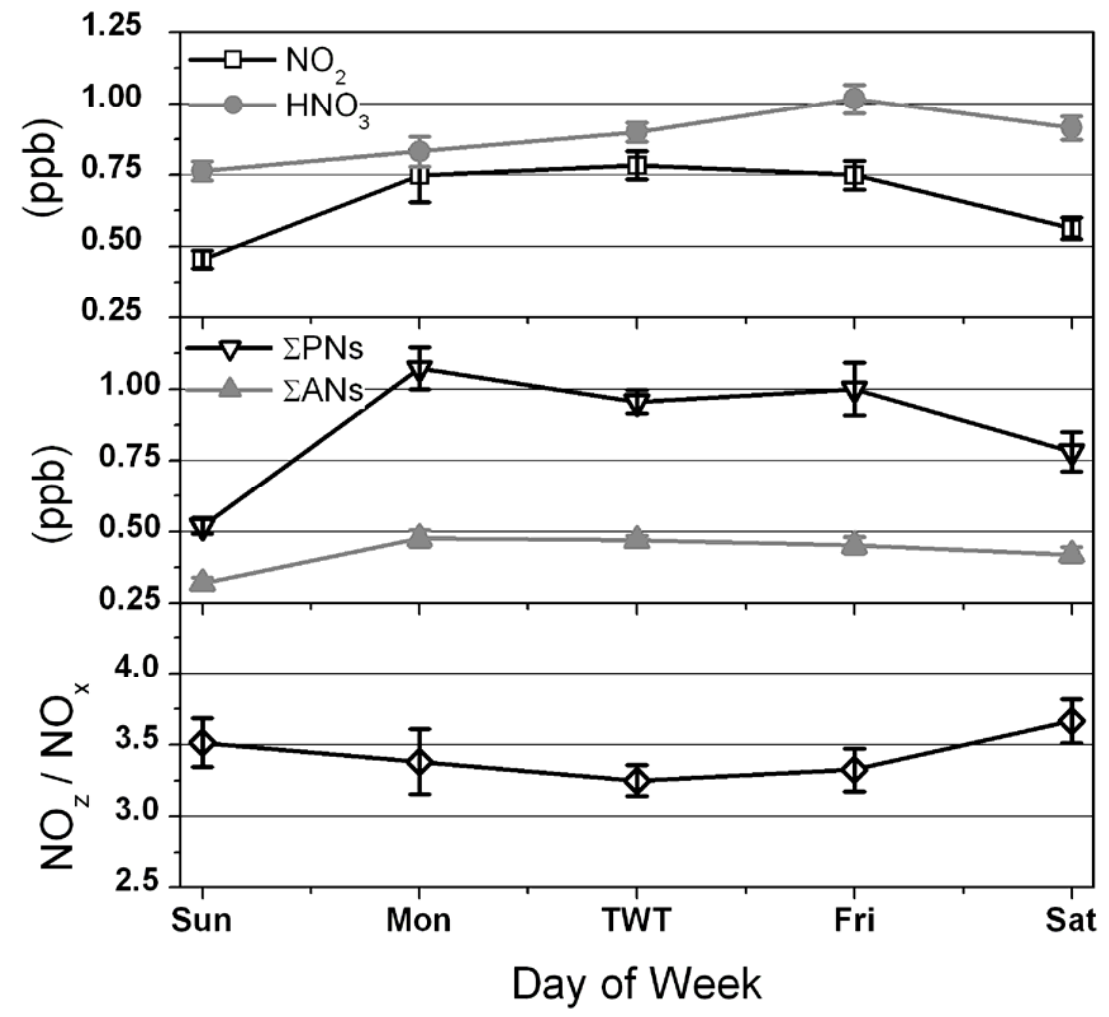

Fig. 14. Speciated $\mathrm{NO}_{\mathrm{yi}}$ observations from UC-BFRS all made between 10:00 and 18:00 during the summer of 2001. The top panel shows measurements $\mathrm{NO}_{2}$ and $\mathrm{HNO}_{3}$. The middle panel shows measurements of sum peroxy nitrates and sum alkyl nitrates. In the bottom panel, the diamonds correspond to the left axis and show the ratio of $\mathrm{NO}_{z}$ to $\mathrm{NO}_{\mathrm{x}}$ in the airmass. $\left(\mathrm{NO}_{z} \mathrm{O} \Sigma \mathrm{PNs}+\Sigma \mathrm{ANs}+\mathrm{HNO}_{3}\right)$. Error bars are twice the standard deviation of the mean.
Weekend effent in

Scaramento: Part 2. Chemistry and transport

J. G. Murphy et al.

\section{Title Page}

\section{Abstract}

Introduction

Conclusions

References

Tables

Figures

14

4

\section{Back}

Close

\section{Full Screen / Esc}

Printer-friendly Version

Interactive Discussion 